\title{
Conceptual Metaphors in Donald Trump's Political Speeches: Framing his Topics and (Self-)Constructing his Persona
}

Kateryna Pilyarchuk* \& Alexander Onysko**

\begin{abstract}
This study investigates the use of conceptual metaphors by Donald Trump in three important political speeches on his way to the US presidency: the acceptance speech of his candidacy, the victory speech on election night, and his inaugural address as president of the US. The consistent analysis of all the metaphors in the speeches shows that Trump relies almost exclusively on conventional conceptual metaphors that are expressed by conventionalised metaphorical expressions. Nevertheless, a range of metaphors appears as constitutive to his framing of political topics, such as immigration and the economy. In addition, Trump metaphorically constructs his political persona as that of a repairman, builder, healer, and warrior, among others.
\end{abstract}

Key words: conceptual metaphor, political discourse, Donald Trump, political speeches

\footnotetext{
* Alpen-Adria-Universität Klagenfurt; kabiletska@edu.aau.at

** Alpen-Adria-Universität Klagenfurt, Department of English; alexander.onysko@aau.at
} 


\section{Introduction}

Trump creates the aura of a super-male talking in abrupt sentences, 'barking', recycling the same words over and over again; he bullies and wants everything that is 'number one'. (Lakoff R. 2017, 598)

The year 2016 has witnessed the success of a highly controversial and unusual political persona - Donald Trump - who became the $45^{\text {th }}$ President of the US. His populist ideas, presumed closeness to the average citizen, and loud statements, such as "I alone can fix it", propelled him to the presidency despite only few political experts believing that he would have serious chances against Hillary Clinton. Trump seems to fit the now popular assumption that people no longer care about politics and instead prefer to be entertained (De Landtsheer et al. 2008, 228). Considering Trump's anti-intellectual use of language (cf., e.g., Degani 2016) questions arise whether metaphors play a role in his political speeches, and, if so, to what extent and in which functions he uses them.

According to Santa Ana (1999), metaphors encountered in political discourse are reminiscent of the now classical love metaphors described in detail by Lakoff and Johnson (1980, 195): they facilitate human understanding of complex concepts by explaining them via bodily experiences and the physical senses. As such, conceptual metaphors in political discourse help to both direct and constrain the audience's understanding by drawing on certain metaphorical themes. Since it is now a widely known fact that people's voting decisions are frequently linked to mental heuristics, or shortcuts, where an individual attends to only one aspect of a problem while ignoring others (Lau \& Redlawsk 2001), aptly used metaphors may help a politician to have the public focus only on those shades of the issue that are favourable for him or her (cf. Bougher 2012, 146). For instance, when deciding whether to vote for Donald Trump, a person may use analogy and resort to one's own experience and background knowledge about the Republican Party that this candidate represents, evaluating the policy of this party and assessing previous Republican presidents. This background knowledge is then enhanced by how a particular candidate presents him- or herself and what her/his political persona looks like. In the case of Trump, metaphors can help to influence voter preferences as in TRUMP IS A WARRIOR ("I will fight for you, and I will win for you; I will fight for you with every breath in my body" ${ }^{\prime 1}$ ), which conceptualises him as a strong, decisive leader and as a warrior who will stand for his people.

In general, metaphor in political discourse has previously been described to bear the following functions: supporting political positioning and ideology, creating a 'myth', increasing emotional effects, and establishing the speaker as a desirable candidate (CharterisBlack 2006, 567). Metaphor can reverberate the rhetorical dimensions of logos, pathos and ethos. The communication of a political ideology is not necessarily based on purely

\footnotetext{
1 This and other illustrative sentences are taken verbatim from Trump's acceptance speech (AS), victory speech (VS), and inauguration address (IA).
} 
factual reasoning. Instead, it overlaps with the pathos component so that reason is framed in a discourse that can leverage particular emotions. In Trump's case, this happens when he applies ANIMAL metaphors (see Section 4.1.3) to evoke fear and distrust towards all immigrants, presenting them as dangerous, wild, and uncontrolled.

According to Mio (1997, 122), one of the major aims of metaphors is to connect the logical (logos) with the emotional (pathos). If a politician embeds metaphors into his or her discourse, they are seeking to frame problems and advocate for a certain course of solutions (Stone 1988). Thus, when Trump, in his acceptance speech (AS), says "Middle-income Americans and businesses will experience profound relief" (metaphor: TAXES ARE PAIN), he understands that it would resonate with the group of citizens tired of paying high taxes. In this case, as well as in the metaphor IMMIGRANTS ARE ANIMALS (see Section 3), Trump diverts attention from other issues and hyperbolises the frames of suffering and fear. According to Van Dijk (2006, 365-66), this is how manipulation in discourse works: since short-term memory is mostly involved in interpreting the meaning of clauses, sentences, and texts when listening to or reading a message, one can easily influence the order of this processing by selecting a bigger font or reiterating certain ideas many times. Trump's constant reference to the same domains ensures that his listeners pick up these metaphors as central. While short-term memory is involved in deciphering the meaning of a text, long-term memory plays a role in the formation of attitudes and opinions (ibid., 367). Thus, if people hear that IMMIGRANTS ARE ANIMALS many times, they are likely to build this ideological model in their mind.

As these initial examples indicate, this article discusses Donald Trump's use of metaphors in his political speeches at the dawn of his presidential career and analyses how they contribute to framing his statements, to influencing his voters, and to building his political image. The study first discusses the data and methodological concerns regarding conceptual metaphors found in the corpus. This is followed by a section on general findings, which includes a discussion on the number and types of metaphors as well as on their significance in the selected speeches. Section 4 focuses on how certain metaphors in Trump's discourse are employed to frame important topics that are on his political agenda. The last section is concerned with how Trump metaphorically constructs his political persona.

\section{Data and methodology}

Virtually every election campaign is characterised by public speeches, during which candidates outline their plans, present their vision for the country's future, and try to persuade the audience to vote for them. The first important address that the candidates deliver to the citizens in the US is their acceptance speech. This speech is crucial as it defines to a considerable extent whether the orator is perceived as competitive and whether she or he has something better to offer than the opponents. Further important 
speeches for incumbent US presidents are the victory speech and the inaugural address. By and large, these are key moments of image construction and persuasion, and they usually abound with various rhetorical strategies and figures of speech, such as repetition, inversion, anti-thesis, and allusions, to name just a few (Schoor 2015, 82-83). Since this paper is concerned with conceptual metaphors, other rhetorical elements will only be taken into account if they are important for the discussion of metaphors.

As mentioned above, our analysis focuses on three key speeches delivered by Donald Trump in the 2016 presidential race: at the beginning of his election campaign, upon his victory, and when he was inaugurated as president. The speeches were obtained from the $\mathrm{CNN}$ website: ${ }^{2}$

1. Donald Trump's Nomination Acceptance Speech (22 July, 2016);

2. Donald Trump's Victory Speech (9 November, 2016);

3. Donald Trump's Inaugural Address (21 January, 2017).

These key moments serve as a basis to examine Trump's use of metaphors in terms of their frequency, uniqueness, and context of occurrence. The particular aim of the study is to find out whether metaphors help to define his dominant political themes and whether they are constitutive to his identity as a politician. How Trump shapes his persona and agenda metaphorically is crucial since, in political discourse, metaphors are known to be powerful persuasive tools (e.g. Charteris-Black 2006, 565; Van Dijk 2006, 361). From a more general perspective, conceptual metaphor analysis in political discourse fits in the wider frame of discourse analysis (cf. Van Dijk 2006) as political persuasion is situated in the interplay of text and language (the discourse aspect) with the social context and its representation in the mind (the cognitive aspect).

In order to identify metaphors in the three speeches, we adopted Conceptual Metaphor Theory (CMT) and applied the Pragglejaz method (Pragglejaz Group 2007; Steen 2007). Conceptual metaphors were described by partly drawing on already established sourcetarget domain descriptions and by postulating new ones as contextually appropriate. In detail, our methodological procedure consisted of the following steps: The speeches were first read without trying to identify the metaphors, rather focusing on the context, tracking Trump's ideas and establishing his message and rhetorical strategies. During the second reading, each article was divided into what Steen $(2007,21)$ refers to as "discourse units". Focusing only on content words, the third step consisted of identifying metaphorical phrases and going through the 5 -step procedure suggested by the Pragglejaz Group (2007). Finally, metaphors were postulated and divided into respective

\footnotetext{
2 - Acceptance Speech (AS):

https://edition.cnn.com/2016/07/22/politics/donald-trump-rnc-speech-text/index.html

- Victory Speech (VS):

https://edition.cnn.com/2016/11/09/politics/donald-trump-victory-speech/index.html

- Inaugural Adress (IA):

https://edition.cnn.com/2017/01/20/politics/trump-inaugural-address/index.html

All last accessed in August 2018
} 
categories, such as person/object/building/machine metaphors. All metaphors were inserted into a table along with the discourse units in which they occurred and the speech in which they were found (see Appendix B). For the general analysis, a frequency table was designed, which shows the total number of metaphors in the three speeches, the number of metaphors in each speech, the number of metaphors that occur only once, and the frequency of metaphors per number of words (see Appendix A and Figure 1). These basic figures summarise the findings and provide an overview of the results. The conventionalised or 'dead' metaphors are not paid much attention to in the qualitative analysis, which focuses on themes in Trump's speeches and on the (metaphorical) construction of his political image.

\section{Findings and General Discussion}

The conceptual metaphors found in the three speeches were categorised according to their source domain, and a basic frequency analysis was conducted. The total number of metaphors amounts to 346, of which 235 (67.9\%) are hapax legomena (i.e. used only once in all the three speeches). In detail, the acceptance speech (AS) contains 211 metaphors, the victory speech (VS) 65 metaphors, and the inaugural address (IA) 70 metaphors. When normalising the frequency of the metaphors according to text length, there is not much of a difference between the speeches: 1 metaphor per 24.2 words $(4.13 \%)$ in AS, 1 metaphor per 24.9 words (4.02\%) in VS, and 1 metaphor per 20.63 words (4.85\%) in IA (see Appendix A). 
Figure 1 shows the 17 categories of conceptual metaphors and their share in the total pool of metaphors.

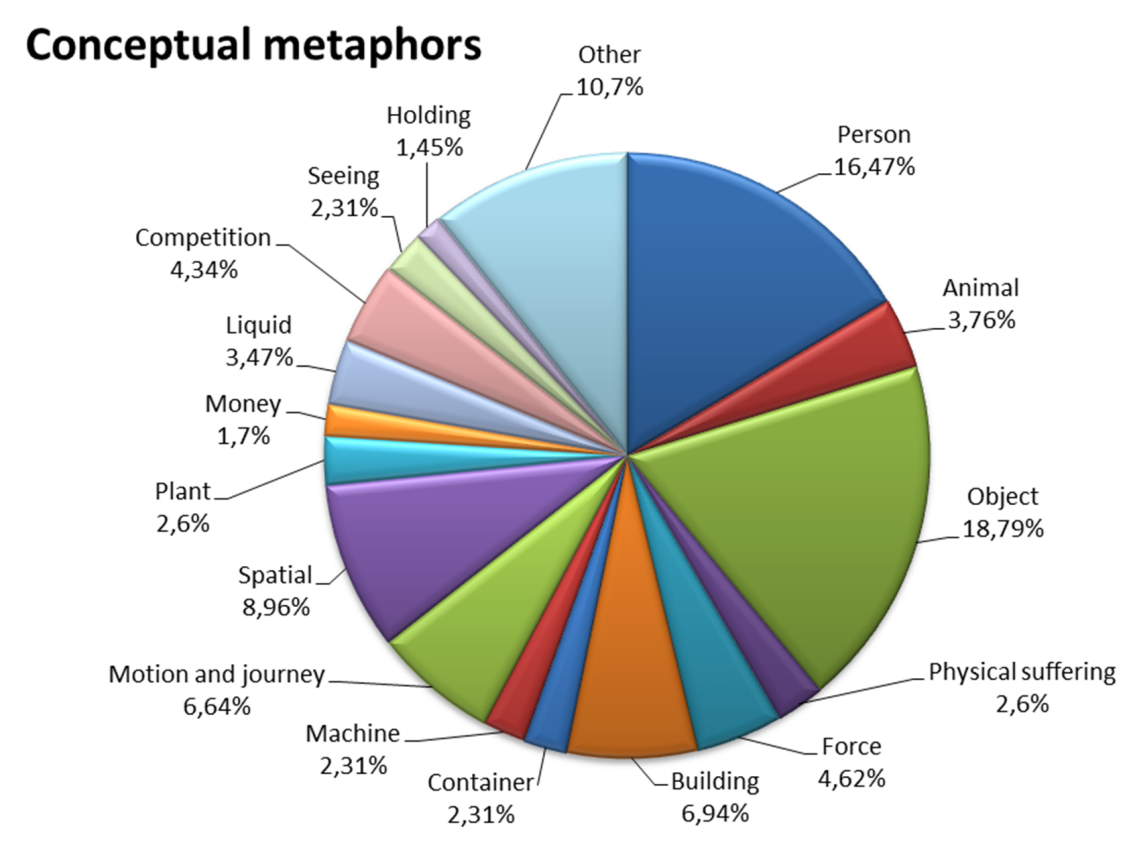

Figure 1: Types of conceptual metaphors (by source domain) in the three speeches

As Figure 1 shows, the biggest groups comprise conventional metaphors with person, object, building, and motion as source domains. The entire list of 346 metaphors is included in the Appendices to provide a general overview of the collected data. While analysing every metaphor clearly lies beyond the scope of the study, it also makes more sense to pay attention to those metaphors that carry a specific purpose in the discourse, in line with Charteris-Black's (2012) notion of 'purposeful' metaphor. Since the political speeches are carefully planned, the metaphors should be discussed in light of the potential aims they pursue such as influencing the audience's attitudes and beliefs, establishing rapport with the public, criticising an opponent, creating an image of a certain type of political persona, and so on. In this sense, it is only of secondary importance whether a metaphor is conventional or not as long as it can be tied to a function in the political speech. According to Pawelec $(2006,118)$, conventional metaphors can be "revitalized" in discourse (cf. Van Dijk 2006 for a cognitive approach in discourse analysis). In our study, some of the person and object metaphors indeed contribute to the construction of Trump's political persona (see Section 5).

Returning to Figure 1, the rest of this section will provide a brief overview of the 17 source-domain categories of conceptual metaphors found in Trump's speeches, beginning with the most frequent types. 


\section{(1) Oвject Metaphors}

In total, 65 metaphors in the data involve instances of objectification, which is arguably one of the most basic types of conceptualisations. Some of the metaphors in this category (e.g., AN OATH IS AN OBJECT) are highly conventionalised, and it is quite unlikely that Trump pursues any particular communicative goal when he uses this metaphor as in "when I take the oath of office" (AS) or "The oath of office I take today" (VS).

On the other hand, the statement "We cannot afford to be so politically correct anymore" (AS), where POLITICAL CORRECTNESS is AN EXPENSIVE ITEM, implies Trump's image of a business person. Similarly, the metaphorisation of PEOPLE AS OBJECTS in "to put the great miners and steel workers of our country out of work" (AS) and "we will put millions of our people to work" (VS) contributes to creating an image which shows that he is in control and can "move" people back into employment.

\section{(2) Person Metaphors}

In this category, the most frequent metaphor is NATION IS A PERSON (26 instances). This can be regarded as a conventional metaphor in political discourse (cf. e.g., Musolff 2010) that reflects basic beliefs about the concept of the nation as a human body and it influences how we perceive messages that contain this metaphor. When Trump says "A nation in mourning" (AS) or "Trade deals that strip us of our jobs, and strip us of our wealth as a country" (AS), he evokes the image of a nation as a sad person; and when he says "We will always put America's interests first" (VS) and "We will seek friendship and goodwill with the nations of the world" (IA), he proposes solutions regarding how to make this ‘sad person' happy again.

In other examples, the physicality of the body (see Ferrari 2007: 615) is at the centre of the metaphor. In expressions such as "Now it is time for America to bind the wounds of division" (VS), and "the crime and violence that today afflicts our nation" (AS), the nation appears as a body experiencing pain, wounds, and mutilation. The same level of conceptualisation is also evident in the metaphor MILITARY IS A PERSON, for which Trump uses the recurrent image of depletion: "our depleted military" (AS), and "depletion of our military" (IA). These metaphors are effective in the emotional dimension as they picture a suffering, bleeding, and wounded body - something that can impress the audience more deeply than an inanimate object or an abstract concept.

Finally, drawing on the POLITICIANS ARE SERVANTS metaphor, Trump frames politics as service to the people. Interestingly, he does not explicitly picture himself as a servant but rather draws on the discursive 'we versus them' dichotomy, like in "My opponent would rather protect bureaucrats than serve American children" (AS). In such a way, he kills two birds with one stone: he positions himself as a servant (which, in his view, Clinton is not) and accuses Clinton of being with 'the elite' rather than the people. 


\section{(3) Spatial Metaphors and (4) Motion and Journey Metaphors}

SPACE and MOTION occur as further fairly frequent source domains in the data. This is not surprising since spatial orientation, just like motion, are very basic image schematic experiences that can play a role in complex conceptualisations. The metaphors CHANGE IS MOTION, FUTURE IS AHEAD, and MORE IS UP are some of the most frequent in the data. Further examples draw on the conceptualisation of sUPPORT IS PROXIMITY (e.g., "Tonight, this candidate and the whole nation stand in their corner to support them", AS), which implies the metaphor of a POLITICAL CONTEST is A BOXING MATCH. Spatial and motion metaphors can also underlie highly conventionalised, idiomatic expressions, such as "I will never, ever let you down" (IA), which expresses the metaphor of DISAPPOINTMENT Is DOwN. In general, these highly conventionalised spatial and motion metaphors can contribute to building Trump's image as a political persona (see Section 5).

In the acceptance speech, Trump uses the metaphor of cyclical motion to talk about human trafficking and violence as well as poverty:

(1) HUMAN TRAFFICKING AND VIOLENCE IS A CYCLICAL MOTION ("the cycle of human smuggling and violence"; AS)

(2) POVERTY IS A CYCLICAL MOTION ("to escape the tremendous cycle of poverty that they're going through"; AS)

These metaphors are close to journey metaphors, which in this article are seen as a subcategory of motion metaphors. LOVE IS A JOURNEY is probably the most well-known metaphor postulated by Lakoff and Johnson (1980). The fact that we imagine life, love, and progress in general as motion in space does not need further comment here. Trump does not draw on the source domain of JOURNEY particularly often in the three speeches. There are three conventionalised references to life is a journey (e.g., "the way of life"; AS) which are accompanied by the genre-specific common metaphorical theme of AN ELECTION CAMPAign IS A JOURNey (e.g., "this 18-month journey"; VS).

\section{(5) Building Metaphors}

The $5^{\text {th }}$ most frequent category of metaphors relying on BUILDING as a source domain emerges from another habitual way of metaphoric thinking. In political discourse, the NATION IS A BUILDING metaphor is a popular rhetorical figure. In the context of Trump's speeches, the BUILDING source domain is of particular importance as it contributes to the construction of his political persona (see Section 5).

\section{(6) Animal Metaphors}

In the data, animal metaphors may be subdivided into three categories:

1. when talking about immigrants and terrorists as in IMMIGRANTS ARE ANIMALS (e.g., "Illegal immigrants with criminal records (ordered deported from our country) are tonight roaming free"; AS). This metaphor is repeatedly used by Trump (see Appendix A). 
2. directed against his opponent: "They are throwing money at her" (AS), implying the metaphor of WASTING IS THROWING A PRECIOUS OBJECT TO AN ANIMAL.

3. in relation to success and hard work: e.g., "I will harness the creative talents of our people" (VS). In this case, TALENTS are metaphorised as DRAFT HORSES.

Among these metaphors, IMMIGRANTS ARE ANIMALs has been analysed in a different context by Santa Ana (1999), who concludes that political discourse generally lacks positive metaphorisations of immigrants. Charteris-Black $(2007,565)$, on the other hand, finds a dichotomy of immigration metaphors: either relating to the positive phenomenon of an increasing birth rate and of helping to overcome the problem of an ageing population or in relation to negative scenarios as leading to unemployment and danger. Since these categories will serve as a point of analysis in the subsequent section, no detailed discussion will be offered here.

\section{(7) Physical Suffering Metaphors}

This category is used by Trump to portray certain issues as painful in his discourse, such as immigration (IMMIGRATION IS PAIN in e.g., "relieffrom uncontrolled immigration"; AS), high taxes (TAXES ARE PAIN in e.g., "Middle-income Americans and businesses will experience profound relief"; AS), bad economic decisions (FINANCIAL LOSS IS BLEEDING in e.g., "subsidized the armies of other countries while allowing for the very sad depletion of our military"; IA), and social division (SOCIAL DIVISION IS A WOUND in e.g., "Now it is time for America to bind the wounds of division"; VS).

Among these metaphors, the term relief is particularly conventionalised. The expression tax relief has dominated Republican political discourse since the Bush (senior) administration and has turned into an emblematic phrase of Republican moral politics (Degani 2015, 181).

\section{(8) Force Metaphors}

The dominant metaphor in this category is DIFFICULTIES ARE OPPOSING FORCES ("the growing threats we face from outside the country"; AS and "We will face challenges"; IA). This is another example of a conventional metaphor that is verbalised in very common expressions. The source domain of FORCE shares some similarity to that of PHYSICAL SUFFERING in Trump's speeches. In both cases, he creates negative metaphoric references to immigrants (3) and to problems supposedly created by his predecessors (4):

(3) "They are being released (by the tens of thousands into our communities) with no regard for the impact on public safety or resources" (AS)

(4) "Not only have our citizens endured domestic disaster, but they have lived through one international humiliation after another" (AS)

By contrast, the source domain of FORCE bears positive metaphoric implications in relation to patriotism (PATRIOTISM IS A FORCE), which Trump claims for his political agenda: 
(5) “A new national pride will stir our souls, lift our sights, and heal our divisions" (IA)

This phrase is mentioned close to the end of Trump's brief inaugural address, where he portrays patriotism (symbolically captured by the American flag) as a uniting power that holds for Americans of all origins and creeds ("we all enjoy the same glorious freedoms, and we all salute the same great American Flag”; IA). What might superficially appear as a message of egalitarianism, is actually tied to the image of all Americans saluting their national flag, i.e. being united by a common action of greeting a symbol of authority. This is not egalitarianism that grows among the people but reinforces a generally Republican vision of authority in governance (i.e. Strict Father Morality, see Lakoff G. 1996).

\section{(9) Container Metaphors}

As one of the 'root metaphors', the container metaphor implies boundaries that separate the inside from the outside of a container. In politics, this image is often applied in the sense that something is closed and needs to be kept this way; any leakage or spill overs have to be prevented (cf. Stone 1988). Chilton $(2004,118)$ discusses the conceptualisation of a country as a closed container (NATION/COUNTRY IS A CONTAINER) where everything that is inside is presumably good, and anything on or from the outside is bad. In Charteris-Black's (2007) point of view, the CONTAINER metaphor is particularly persuasive because it blends the concepts of TIME and SPACE implying that CONTROL OVER SOCIAL CHANGE IS CONTROL OVER MOVEMENT OF PEOPLE, something that holds true in the case of 'refugees' and 'drugs' in our data:

(6) "existing massive refugee flows coming into our country"; (AS)

(7) "to stop the drugs from pouring into our communities"; (AS)

The movement of people and harmful substances from the outside 'weakens' the walls of the container (cf. Charteris-Black 2007: 577). Examples (6) and (7) show that Trump uses the CONTAINER metaphor to say that it is safe inside the container of the US and threatening outside, which underlies the physical manifestation of building a wall to "protect” the US (cf. Chilton 2017, 585).

More rarely, Trump uses the THE US IS A CONTAINER metaphor in the reverse sense. This is the case when beneficial substances (as valuable possessions) are said to flow into the nation (e.g., "trillions of dollars will start flowing into our country"; AS).

\section{(10) Machine Metaphors}

The MACHINE metaphor is often applied to describe the unity and integrity of components. An example of that is the clock, which is a self-regulatory system where the tiniest parts are in harmony (Ezrahi 1995, 312). In his acceptance speech, Trump evokes the SOLVING PROBLEMS IS FIXING A MACHINE metaphor 5 times, using the lexical expression 
of fixing something (e.g., "we are going to fix the system", and "we can fix this problem so quickly"). Describing a nation as a machine, a mechanism where every single part matters, is likely to have strong influential power on the people, who want to participate in growth of their nation and feel their own value. This metaphor contributes to Trump's image as discussed in Section 5.

\section{(11) Plant Metaphors}

Trump conceptualises money as a plant to speak about abundance: MONEY ARE CROPS ("A small group in our nation's Capital has reaped the rewards of government"; IA), or A LOT OF MONEY IS AN ABUNDANCE OF LEAVES ("Secretary of State rakes in millions and millions of dollars"; AS). He also falls back on the conventional metaphor of weeds to refer to unwanted entities that are conceptualised as being invasive: TERRORISM IS A WEED (e.g., "radical Islamic terrorism, which we will eradicate completely"; IA). Some other metaphors in this domain contribute to the building of his image as a politician (see Section 5).

\section{(12) Money Metaphors}

The source domain of MONEY is used to present Trump as a business mogul, who measures everything for its financial value. Examples in this category emphasise once more his discursive reliance on conventional metaphorical themes, which are expressed by highly conventional lexical means. This is evident in the use of the metaphor TIME Is MONEY (e.g., "time I have spent with the mothers and fathers"; AS, or "spent my entire life in business"; VS), which is deeply rooted in the US culture (see Lakoff \& Johnson 1980, 7-9), in PERSONAL RELATIONS ARE BUSINESS (e.g., "we will deal fairly with everyone"; VS), and in GRATITUDE IS MONEY ("we owe her a major debt of gratitude"; VS). In addition, Trump uses the money domain non-metaphorically to establish an analogy between his own persona as a "successful" business man and his function as head of state ("I have made billions of dollars in business making deals - now I'm going to make our country rich again" in AS is just one out of many examples).

\section{(13) Liquid Metaphors}

Our study is in line with the findings by Charteris-Black (2007: 569), who observes that 'fluids', like natural disasters, frequently shape the theme of immigration and that the FLUID and the CONTAINER domains interact in that imagery. In Trump's discourse the country is conceptualised as a container that needs to be protected from WATER/FLOOD from the outside, which is instantiated in the metaphor VIOLENCE IS AN OVERFLOwING LIQUID (e.g., "violence spilling across our border"; AS).

\section{(14) Competition Metaphors}

As Gibbs $(2015,279)$ observes based on the results of empirical studies, people perceive politics as a competitive sport, in particular as a boxing match. This is most of all true 
of political debates during election campaigns. While our data also contains a number of metaphors that draw on the imagery of competition, we only pay close attention to those metaphors that concern the self-representation of Trump, as in TRUMP IS A WARRIOR (e.g., "I will fight for you with every breath in my body"; IA).

\section{(15) Seeing Metaphors and (16) Holding Metaphors}

The source domains of SEEING and HOLDING give rise to metaphors that structure basic conceptualisations of mental states. In our data, however, metaphors such as BELIEving IS SEEING Or UNDERSTANDING IS HOLDING do not contribute to the framing of themes or to building Trump's image. They are listed in the Appendices as part of the complete analysis but will not be discussed further.

\section{(17) Other Metaphors}

This last category accommodates the metaphors that only occur once or a couple of times so that they do not form separate groups in the data. Since the scope of this article does not allow for a detailed analysis of each of these 37 items, the most important ones will be incorporated into the further analysis of themes and the self-representation of Trump's political persona in the sections that follow.

In general, the overview of the different metaphor types (classified by their source domains) that occur in Trump's three key political speeches on his way to the US presidency indicates that his discourse relies on conventionalised metaphors which are often conventionally expressed. In this sense, Trump's use of metaphors falls in line with a common characteristic of political discourse as already observed some time ago by Edelman (1964, 124-125). He notes that politicians tend to repeat "clichés and stale phrases" which reinforce latent beliefs or reference frames (also see Mio 1997 for a discussion of conventionalised metaphors in political discourse). Among the range of metaphors that can be detected in Trump's speeches, those are of particular interest which reflect his framing of certain political ideas and which help to create the image of his political persona. Sections 4 and 5 will focus on these aspects.

\section{Themes in Trump's Discourse}

This section analyses dominant themes that Trump addresses in the selected speeches with a particular focus on the metaphors he uses. Trump's discourse is in line with the Strict Father Morality characteristic of Republican moral politics (cf. Lakoff G. 1996, 187-194) when he talks negatively about immigration and taxes (see Section 4.1). His messages also reflect populist ideas (cf. Wodak 2015; Oliver \& Rahn 2016), and some of the metaphors discussed in the following are further examples of that. Chilton (2017, 592) defines populism as "a discourse that works by activating emotion-laden and valueladen schematic concepts and concomitant emotions, rather than using overt argument 
and evidence". Metaphors can contribute to populist discourse since they help to create emotions and to evoke value-laden associations in the audience.

\subsection{Otherness: Other Nations and Immigration}

\subsubsection{The Frame of Fear}

The populist discourse in Europe and America is currently associated with threats coming from 'others', immigration as a negative phenomenon, and the need to prioritise citizens over immigrants when distributing jobs (cf. Wodak, 2015). Thus, 'we' is always strongly emphasised and 'they' are demonised as part of a nationalist agenda (Oliver \& Rahn 2016, 191). Trump conceptualizes America as a contained entity that has to beware of enemies from the outside. He metaphorises other nations as thieves when he says in his IA, "we must protect our borders from the ravages of other countries" and "other countries stealing our companies and destroying our jobs". Both terrorism and immigration are related to the frame of fear (Charteris-Black 2006, 574). They are often combined in populist reasoning, giving rise to the implication that terrorists arrive in a country along with immigrants seeking asylum. An illogical assumption is built up: the fact that some immigrants come illegally to the nation means that they might be terrorists, leading to the more general assumption that all immigrants are potential terrorists (Charteris-Black 2006, 574). In his speeches, Trump constructs the frame of fear towards immigrants, who can 'steal' jobs from the American citizens, turn out to be terrorists, and kill everyone (e.g., 11, 12, 15). Trump himself does not draw a clear line between the two groups, and his discourse at the macro-level points to his racist views, where anyone who is not American should be feared and viewed as non-human (e.g., 13, 16). These people are depicted by him as inferior and lacking morality (cf. Shafer, 2017).

\subsubsection{Container and Liquid Metaphors}

The theme of immigration is not unique to the US. As Montgomery (2017, 622-623) puts it, the recent concern was initiated by the UK planning to leave the EU and 'sealing' the country as a container (Charteris-Black 2006). Conceptualising immigrants as a disaster that threatens the inside of the 'container' (i.e. the US) encourages people to dissociate with immigrants (8). More so, the immigrants are not conceptualised as agents in Trump's discourse. They are 'water' or a 'flood'. This dehumanised lexicalisation can hardly evoke any empathy in the audience.

(8) A COUNTRY Is A CONTAINER ("This is not believable, but this is what's happening - refugees on top of existing massive refugee flowes coming into our country under President Obama"; AS)

In Trump's metaphors, the frame of containment is associated with that of liquids because a container can be filled, and liquids can overflow. It can also be ruined by an 
excessive amount of liquid (9). Given the US history of hurricanes and frequent warnings of floods, the issue of 'flooding' becomes even more ominous.

(9) IMMigRATION IS A FLOOD ("existing massive refugee flows coming into our country"; AS)

By comparing immigration to a flood, Trump also contributes to the myth that immigration is as extensive and uncontrollable as a natural catastrophe. As Demata (2017, 282-283) points out, the flood metaphor is a frequent figure of speech in populist political discourse, and Trump uses it as his major topos when referring to immigration as a threat.

While the word 'immigrant' or 'immigration' is not always explicitly mentioned, it can be read between the lines or emerges in the larger context in some instances. Social vices, such as drugs and violence, are associated with 'others' coming from across the border, as shown in (10) and (11).

(10) COMMUNITIES ARE CONTAINERS / DRUGS ARE AN UNCONTAINED FLOW OF WATER ("We are going to build a great border wall to stop illegal immigration, to stop the gangs and the violence, and to stop the drugs from pouring into our communities"; AS)

Example (10) is yet another case where containment and liquids make a mutual contribution to the frame of fear. A specific instance of the CONTAINER metaphor is the CASTLE metaphor, as proposed by Santa Ana $(1999,206)$. The image of a castle highlights the notions of ownership, preciousness, and protection as strong walls separate the inside from the outside. There is also a connection to another possible metaphor IMMIGRANTS ARE CONQUERORS: they come with bad intentions (drugs and violence) and take possession of the territory.

In the case of 'overflowing water' that is uncontrollable, Trump positions himself as a warrior standing on the same side of the barricades as his audience resisting the 'violence as liquid' that is supposedly threatening the US (11).

(11) VIOLENCE IS AN OVERFLOWING LIQUID ("who have lost their children to violence spilling across our border"; AS)

In terms of the 'we versus them' dichotomy (see Van Dijk 1998; 2006), the illegal penetration into the country is a symbolical entering of 'them' into 'us' because 'we' are inside the container. Charteris-Black (2006, 576-577) compares NATION IS A CONTAINER to BODY IS A CONTAINER. He says that humans are in a position to consciously control what comes in and out of the container. Similarly, Trump calls for controlling the 'national container' by erecting a wall (12), an idea that runs like a red thread through his discourse. In this frame of fear, Trump emerges as a saviour of the container, protecting it from penetration. 
OPEN BORDERS ARE AN ALTAR FOR RITUAL SACRIFICE ("One more child to sacrifice on the order and on the altar of open borders"; AS)

The fact that some immigrants indeed come to the US by water might have reinforced the occurrence of the metaphors in (8) to (12). Charteris-Black $(2006,572)$ makes a similar point about discourse on immigration during the elections in Britain in 2005. In general, the use of such metaphors on immigration both simplify the audience's understanding of the complex problem and trigger the cognitive frame of fear from a natural disaster. As Ferrari (2007, 617-619) claims, there is always a counterbalance in the fear frame: whereas the outside is portrayed as dangerous and filled with monsters, the inside is a safe haven. In other words, a political candidate that evokes the frame of fear can, at the same time, present him/herself as the protector from that fearful thing to happen. This is a frequent strategy of populist discourse and Trump is no exception to that.

\subsubsection{Animal Metaphors}

Santa Ana (1999, 196) claims that political discourse frames problems by means of metaphors, which can highlight certain aspects while blinding out others. Calling immigrants 'animals', both in the texts of his speeches and via his Twitter account (which is not the focus of this research but reinforces the point), Trump aims at building a strong association in the minds of his potential voters. The metaphor IMMIGRANTS ARE ANImALs (13) is very frequent in Trump's discourse and also in the three key speeches analysed in this study. Among others, it testifies to his xenophobic attitudes.

(13) IMMIGRANTS ARE ANIMALS

13.1 "Illegal immigrants with criminal records ordered deported from our country are tonight roaming free"; AS

13.2 "They are being released (by the tens of thousands into our communities) with no regard for the impact on public safety or resources"; AS

13.3 "One such border-crosser was released"; AS

13.4 "On Monday, we heard from three parents whose children were killed by illegal immigrants. Mary Ann Mendoza, Sabine Durden, and my friend Jamiel Shaw. They are just three brave representatives of many thousands who bave suffered so gravely. Americans who have been so brutally murdered, and who have suffered so so horribly"; AS

When he speaks about 'releasing' immigrants, one readily accesses the frame of a cage, which, once opened, lets out wild animals that pose danger to people (13.2) and (13.3). Once released, these immigrants are 'roaming freely', which reinforces an image of fear. The place where wild animals can roam freely is typically a jungle rather than an inhabited city (13.1).

The brutal and savage nature that Trump ascribes to 'others' (e.g., 13.4, 15, 16) again draws on the frame of the wild: a brute cannot be tamed. This metaphorical mapping 
is prevalent in the description of terrorism as well and emphasises that Trump does not draw a clear line between terrorists and immigrants (for a similar observation drawn on different data, see Demata 2017, 284).

(14) TERRORISM IS AN ANIMAL ("brutal Islamic terrorism"; AS)

(15) A TERRORIST IS AN ANIMAL ("Americans were savagely murdered by an Islamic terrorist"; AS)

(16) TERRORISTS ARE INSECTS ("stamping out Islamic terrorism"; AS)

That people can be conceptualised as animals is not a new metaphorical mapping. Lakoff and Turner $(1989,166-180)$ took the theoretical basis from Aristotle and Plato and discussed how the Great Chain of Being may serve as a model of metaphorical mappings. The Great Chain of Being, which is particularly rooted in western cultures, consists of 5 levels: God - humans - animals - plants - inorganic matter. They are located hierarchically one after the other, with God at the highest level and inorganic matter at the lowest. Since animals are located lower than humans, it is clear that such a mapping implies the superiority of humans. The comparison of terrorists to insects in one instance exemplifies this superiority relation. Insects are small invertebrates that can be 'stamped out' easily and destroyed (16) according to Trump.

\subsubsection{Disease and Murder Metaphors}

When operating within the frame of disease, physical wounds and pain are immediate associations. They form part of the impressive (and in political terms persuasive) power of metaphors that draw on the source domain of disease. (17) and (18) show how Trump uses this metaphor to present himself as a healer who is going to prevent immigration and crime metaphorised as pain and disease.

(17) IMMIGRATION IS PAIN ("relief from uncontrolled immigration"; AS)

(18) CRIME AND VIOLENCE IS A DISEASE ("The crime and violence that today afflicts our nation will soon - and I mean very soon - come to an end"; AS)

The physical aspects (cf. Ferrari 2007) of disease and pain give rise to further metaphors (19 and 20), which underline Trump's exploitation of that imagery.

(19) SERIOUS PROBLEMS ARE SLAUGHTER ("This American carnage stops right here and stops right now"; IA)

(20) Emotional SUFFering is a PHysical wound ("wounded American families"; AS)

(19) occurs in the context of Trump accusing immigrants of killing peaceful residents. The same implicit reference to the brutality of immigrants and pain inflicted by them is expressed in (20), in which the emotional suffering over the loss of family members is equated with being physically wounded. 


\subsection{Opponents and Previous Presidents}

In populist political discourse, opponents are a crucial theme. They are not only conceptualised as 'others' with a different agenda and values, but they also tend to be seen as a threat (Kreis 2017, 609). The way that Trump talks about his predecessors and his main rival in the election - Hillary Clinton - is reminiscent of his conceptualisation of immigrants and terrorists: they rob people, they prey on their wealth and happiness, and they threaten their peace and stability. Thus, the dichotomy of 'we versus them' is again meant to influence the audience's mental model (see Van Dijk 2006, 370). Trump is searching for culprits, and he proposes easy answers: 'others' have done it to the country (21). He is engaged in blaming these 'others' for conspiracy, an aspect that Wodak $(2015,20)$ defines as key in political populism. Similarly, Oliver and Rahn (2016, 200-201), comparing the voters of different 2016 presidency candidates, claim that Trump's supporters are inclined to believe in conspiracy scenarios and appear financially pessimistic - the opposite of what Clinton's voters are.

(21) BAD POLITICS Is CHAINS ("we must break free from the petty politics of the past”; AS)

While (21) shows an indirect blame - the blame put onto 'the past' politicians without mentioning concrete names - Trump does not mind pointing fingers and 'scapegoating' others saying that they bear responsibility for all the social woes (cf. Kreis 2017, 616). Thus, (22) to (24) are examples which demonstrate that he assigns a concrete fault to a specific politician, at the same time alluding to his own political work as an attempt to mend the mistakes made by the others.

(22) A TRADE DEAL IS A DESTRUCTIVE FORCE ("America has lost nearly-one third of its manufacturing jobs since 1997, following the enactment of disastrous trade deals supported by Bill and Hillary Clinton”; AS)

(23) A MISTAKE IS A DESTRUCTIVE FORCE ("She supported NAFTA, and she supported China's entrance into the World Trade Organization - another one of her husband's colossal mistakes and disasters"; AS; "her bad instincts and her bad judgments are what caused so many of the disasters unfolding today"; AS)

(24) OBAMACARE IS A DESTRUCTIVE FORCE ("We will repeal and replace disastrous Obamacare"; AS)

Examples (22) to (24) demonstrate what Van Dijk $(1998,2006)$ refers to as conceptualdiscourse self-presentation, which happens both on macro- and micro- levels. The overall theme of otherness is shaped by Trump demonising 'them', de-emphasising their merits or erasing them altogether. At the same time, he hyperbolises his own merits and presents his actions as the only possible way out. In this context, it is also the lexical choice that relates to the metaphorical source domain of a destructive force, which influences the audience to visualise the scope of 'their' negative sides and his positive 
sides. In (22) - (24) the noun 'disaster' and the adjective 'disastrous' allude to natural catastrophes, all-mighty forces, and destruction that can sweep away everything. The US history of hurricanes creates a contextual setting that can further build up fear among the audience: they have to beware of the politicians who bring about disaster and follow the one - i.e. Trump - who "knows" how to prevent this disaster.

Interestingly, Trump does not only depict Obama and the Clintons as a Destructive FORCE, but also blames them for fuelling immigration (25). In this way, he creates a common frame of 'others' who are either conceptualised as a threat or as misguided and inferior politicians.

(25) immigrants ARE A DeStRUCtive ForCe ("They are being released (by the tens of thousands into our communities) with no regard for the impact on public safety or resources"; AS)

In his criticism of political opponents, Trump falls back on metaphors involving physically threatening imagery (cf. Ferrari 2007, 615). This makes the presumed danger associated with his opponents more tangible (26).

(26) AUTHORITY IS PHYSICAL POWER ("the powerful can no longer beat up on people"; AS)

In (26), Trump plays with the connotation of the word 'powerful'. The 'powerful' aspect of his leadership is positive (since it makes him a strong head of state capable of protecting the poor), whereas the 'powerful' aspect of the others is negative (since it implies their intention to cause suffering and impose their power on the poor). What is also striking in Trump's discourse is how he makes 'others', especially Hillary Clinton, responsible for all the problems in the US. He insinuates that Hillary Clinton's actions depend on some higher authority who tells her what to do and which decisions to take. Trump calls Clinton a puppet $(27,28)$ without mentioning any names of the supposed puppet masters and without explaining what exactly he refers to, i.e. without any proof whatsoever (also see Lakoff R. 2017, 597).

(27) BEING UNDER CONTROL IS BEING A PUPPET ("She is their puppet"; AS)

(28) MANIPULATING Is PULLING STRINGS OF A PUPPET ("They pull the strings"; AS)

Trump accuses Clinton of being manipulated by the wealthy elite, who is the biggest enemy of the populist politician, and it is quite striking that Trump gets away with that while being a billionaire himself. In this context, it is worth mentioning that Trump speaks of 'the people', the definite article presupposing that he is referring to the citizens of the US. They have been betrayed, and he is now here to give them his helping hand (cf. Chilton 2017, 589, for a comparison with Obama's discourse about 'people' in general). Trump's framing of Clinton as a toy in the hands of the elite is emphasised 
in another metaphor that is targeted at decrying his opponent. The elite are wasting money by investing in her (29).

(29) WASTING is throwing a PRECIOUS OBJECT to AN ANIMAL ("They are throwing money at her"; AS)

The metaphor in (29), is evoked by a conventional idiomatic phrase (related to the Biblical proverb of 'casting pearls before swine', Matthew 7:6) which can be read as an implicit comparison of Clinton with an animal. This is yet another example of Trump's populist discourse, which is characterised by indecency or, as Oliver and Rahn (2016, 191) put it, by behaving "like a drunken guest" disrupting a party with "bad manners".

\subsection{Economy, Business, and Trade}

Given Trump's financial wealth, his conceptualisation of the economy is intrinsically linked to his way of doing business. He talks about the economy and trade by drawing comparisons to his making of business deals. While he emerges as a good and righteous person in these affairs, other politicians, such as his opponent, are blamed for striking bad and thus immoral deals (30).

(30) A TRADE DEAL IS AN IMMORAL PERSON

30.1 "trade deals that strip us of our jobs, and strip us of our wealth as a country"; AS

30.3 "borrible and unfair trade deals"; AS

30.3 "job killing trade deal"; AS

The theme of the economy is addressed in three major topics: the depleted economy, revitalisation of the economy, and products. To conceptualise what he deplores as a decaying state of the country because of his predecessor and opponents, Trump's metaphors again draw on physical source domains (31-33).

(31) FINANCIAL LOSS IS BLEEDING ("subsidized the armies of other countries while allowing for the very sad depletion of our military"; IA)

(32) TAXES ARE PAIN ("Middle-income Americans and businesses will experience profound relief"; AS)

(33) BAD AGREEMENTS ARE PAIN ("agreement that hurts our workers"; AS)

The metaphor on the topic of the depleted economy and economic problems is another example that relies on the source domain of FLOOD as an uncontrolled and harmful flow of water. Similar to his discourse on immigration (see Sub-section 4.1.2), Trump uses the frame of a flood to conceptualise all kinds of events. In his announcement speech, Trump employs the idiomatic phrase "to drown in debts" to evoke a metaphor based on water as a harmful substance (34). 
(34) DEBTS ARE A DEADLY FLOOD ("students who are drowning in debt"; AS)

When analysing Trump's rhetoric, it becomes evident that he relies on the same conceptual frames for presenting different issues. Water, for instance, not only serves to conceptualise danger (immigrants, terrorists, drugs, and violence) but also money as in (35) and (36). Trump's discursive role changes accordingly. When talking about immigration, he promises to safeguard the 'container' (i.e. his country) and not let anyone in (because the 'container' cannot accommodate "dangerous" foreigners). The money of foreigners, on the other hand, is seen as a welcome 'penetration' because the container has room for investment.

(35) MONEY IS FLOWING WATER ("trillions of dollars will start flowing into our country"; AS)

(36) MONEY IS WATER ("flush with cash"; IA)

Trump's business approach is also noticeable in other issues that he measures in terms of costs and value. Political correctness, for example, is given a price tag, too (37).

(37) POLITICAL CORRECTNESS IS AN EXPENSIVE ITEM ("We cannot afford to be so politically correct anymore"; AS)

Shafer (2017) believes that what has come to be known as Trump's 'political incorrectness' is an expression of neoliberal progress closely related to the supremacy of hegemonic whiteness and fear of other races. For Trump, being polite and tolerant to other people appears as a too expensive product and time consuming behaviour. He sells a lack of sensitivity for human concerns to his audience by drawing on the capitalist conceptualisation of time as money. Wasting time on looking for the appropriate words to discuss sensitive topics means losing time that could otherwise be spent on more important, and 'less expensive', problems.

Trump's substitute for political correctness is being straightforward and direct, as shown in (38) and (39). He also implicitly opposes Clinton's 'feminised' political correctness (cf. Johnson 2017). This plainness and directness falls in line with a STRICT FATHER $^{3}$ morality of Republican discourse, in which the voice of authority speaks without trying to sugar-coat facts.

\footnotetext{
3 For more on the STRICT FATHER vs NURTURANT PARENT models of Republican vs. Democratic political morality see Lakoff G. (1996), and for applications Cienki (2005) and Degani (2015).
} 
(38) TRUTH IS STRAIGHT ("It is finally time for a straightforward assessment of the state of our nation"; AS)

(39) TRUTH IS PLAIN

39.1 "I will present the facts plainly"; AS

39.2 "I will tell you the plain facts"; AS

The metaphor TRUTH IS STRAIGHT also implies that the opponent does not tell the truth. For Trump, political correctness is synonymous to lies while his 'incorrectness' is an expression of honesty.

\section{Trump's Political Image}

In political discourse, a politician does not solely aim at persuading her/his audience but pursues a number of other goals, such as representing the course of action, taking position in relation to certain topics, expressing attitudes towards political opponents, and, finally, shaping one's own political identity (Martin 2013, as cited in Schoor 2015, 84-85). Experts in political marketing have become aware of the fact that a distinct profile of the political candidate is of primary importance for winning elections (De Landtsheer et al. 2008, 218). De Landtsheer et al. (2008, 220) also talk about modern politics as "perception politics", in which style and personality play more important roles than lines of argumentation. This claim is supported by Degani (2016, 131), who states that voters tend to base their preferences of a particular candidate not so much on what they promise but rather on the image they create for themselves. This, in turn, goes back to Aristotle's model and the primacy of ethos and pathos over logos, which explains to a certain extent why the latest US elections yielded such a result. Donald Trump managed to present himself in a way that made him more appealing than Hillary Clinton to large parts of the electorate. The last section of this article aims at exploring how Trump uses metaphors to self-construct his political identity in the three key speeches. The different metaphorical self-images will be discussed in individual sub-sections.

\subsection{ENGINEER and REPAIRMAN}

Gibbs $(2015,265)$ suggests that the audience not necessarily recognises every single metaphoric concept in a political speech. It is rather the case that listeners will catch the overall symbolic idea and "allegorical themes" that are constructed in the narrative of a politician. The FIXING domain, expressed in Trump's stock phrase "I alone can fix it" (AS), has become what De Landtsheer et al. (2008) refer to as "a sound bite" or a recognisable catchphrase (40). By using that expression, Trump does what Montgomery $(2017,627)$ calls "turning up the discursive volume". According to the 
function of amplification in discourse, the speaker should indeed make strong, perhaps even hyperbolised, statements to convey a message effectively. Trump's rhetoric leaves no room for 'turning the volume up further'. Although he slightly adjusts the phrase in his speeches, sometimes replacing 'I' by 'we', in order to create the impression that his voters are also engaged in the decision making, the underlying metaphor works for his own image - Trump emerges as an engineer that knows how machines work and how to detect malfunctions that (only) he can mend.

(40) SOLVING PROBLEMS IS FIXING A MACHINE

40.1 "Nobody knows the system better than me, which is why I alone can fix it"; AS

40.2 "we will fix this biggest single issue"; AS

40.3 "we can fix this problem so quickly"; AS

40.4 "to fix our inner cities"; AS

Operating with the frame of MACHINE, Trump achieves yet another aim - he conceptualises the US as a horizontal rather than a hierarchical structure. According to Ezrahi (1995, 316-317), a MACHINE metaphor gives the impression of egalitarianism, harmony, and order, where the movement of every part pre-defines the movement of another part, like in a clockwork (41-42).

(41) THE POLITICAL SYSTEM IS A MACHINE ("to fix the system so it works justly for each and every American"; AS)

(42) TRANSPORTATION SECURITY ADMINISTRATION IS A MACHINE ("we will fix TSA at the airports"; AS)

As part of his image as a repairman, Trump promises to solve problems whereas his opponents fail to do so. By implication they are bad engineers since their system is malfunctioning.

\subsection{Constructor and Controller}

Apart from the job of an engineer and repairman, Trump also promises to take on the related role of a constructor. A NATION IS A BUILDING (43) is a very common metaphor. It builds on a primary CONTAINER metaphor as it conveys the idea of protection and the image of a walled structure, where the inside is home and the outside is alien. Trump frequently uses the BUILDING source domain in the sense of rebuilding the nation. 
(43) A NATION IS A BUILDING

43.1 "On the economy, I will outline reforms to add millions of new jobs and trillions in new wealth that can be used to rebuild America"; AS

43.2 "We will get our people off of welfare and back to work - rebuilding our country with American hands and American labor"; IA

43.3 "we will begin the urgent task of rebuilding our nation"; VS

Using the term 'restore', Trump evokes the building theme in reference to abstract concepts such as peace, safety, and law, as in (44) to (46). This reification creates associations to stability and resistance. By implication, he once again creates a dichotomy of 'we versus them' since the others have left these metaphorical buildings in such a bad state.

(44) PEACE IS A BUILDING ("It won't be happening very much anymore. Believe me. Peace will be restored"; AS)

(45) SAFETY IS A BUILDING ("Beginning on January 20th of 2017, safety will be restored"; AS)

(46) LAW AND ORDER IS A BUILDING ("I will restore law and order to our country"; AS)

Trump's political persona as a constructor and controller is also evident in the way he talks about people, who can be moved around just like objects (47).

(47) PEOPLE ARE OBJECTS

47.1 "we will put millions of our people to work"; VS

47.2 "We will get our people off of welfare and back to work"; VS

Similarly, jobs are conceptualised as objects, and Trump assumes the role of the one who can bring these objects back into existence (48).

(48) A JOB IS AN OBJECT

48.1 "I am going to bring our jobs back to Obio and Pennsylvania and New York and Michigan and all of America"; AS

48.2 "We will bring back our jobs"; VS

Overall, his metaphorical image as a constructor and controller adds to his appearance as a confident and independent agent - as the one who decides and acts.

\subsection{Healer}

Quoting Falkowski and Wojciech (1999), De Landtsheer et al. $(2008,220)$ say that people do not vote with their mind but with their heart. Since health is a prerequisite of happiness and wealth for everyone, it appeals strongly to people's emotions. Conceptualising the nation as sick evokes strong adverse reactions from the public, more so if 
the supposedly guilty ones are named. In his speeches, Trump emerges as a healer of the nation and its citizens (49-52).

(49) A NATION IS A PERSON ("We Will Make America Strong Again"; AS, IA)

(50) SOCIAL DIVISION IS A WOUND ("Now it is time for America to bind the wounds of division"; VS)

(51) EMOtional SUfFering Is A PHYSical wound ("These wounded American families have been alone. But they are alone no longer"; AS)

(52) TAXES ARE PAIN ("Middle-income Americans and businesses will experience profound relief”; AS)

These statements do not offer any concrete solutions, but they attempt to be persuasive by way of promise as in (49) and (52), by making an appeal for action (50), and by stating a change of conditions supposedly brought about by the speaker. These utterances are also examples of what Mio $(1997,124)$ calls "pseudo-deductive reasoning". Trump introduces a point which is made believable by using a metaphor that appeals to the cognitive frame of pain. While pain is bad, Trump turns into a 'healer' as he offers a solution to this painful state. The source domains of PAIN and PHYSICAL SUFFERING give rise to further metaphors that relate to the theme of immigration (53) and the economy (54). In (55) Trump's partaking in the pain of others is metaphorised by the conventional mapping of depth to intensity.

(53) PROBLEMS ARE PHYSICAL SUFFERING ("We are one nation - and their pain is our pain"; IA)

(54) BAD AGREEMENTS ARE PAIN ("She supported the job killing trade deal with South Korea. She has supported the Trans-Pacific Partnership [... I I pledge to never sign any trade agreement that burts our workers"; AS)

(55) EMOTIONAL INTENSITY IS DEPTH ("Nothing has affected me more deeply than the time I have spent with the mothers and fathers who have lost their children"; AS)

In (54) Trump not only constructs his persona as a healer, but he also puts blame on his opponent. Clinton becomes responsible for the workers' state of sufferance.

\subsection{SAVIOR / WARrior}

According to Wodak (2015), a populist politician always presents him- or herself as a charismatic leader who assumes the role of a modern-day Robin Hood and cares about the welfare of the people. In the discursive construction of his image as a politician, Trump claims this role as well. He talks about difficulties and resistance, implying that he will save the US and its citizens from these problems, as in (56) and (57). 
(56) DIFFICULTIES ARE OPPOSING FORCES

56.1 "The growing threats we face from outside the country"; AS

56.2 "We will confront hardships"; IA

(57) RESISTANCE IS REMAINING UPRIGHT ("I have a different vision for our workers. It begins with a new, fair trade policy that protects our jobs and stands up to countries that cheat"; AS)

Hyperbolising the problems and conceptualising them as either chains (58) or dangerous locations (59), Trump further contributes to the frame of fear and places the blame on those before him (cf. Johnson 2017). In (59) he addresses a particularly sensitive topic that appeals to emotions. Children need protection and shelter, and they are the future of the nation. Anxiety is further enhanced as Trump refers to suffering children in his framing of immigrants as criminals (e.g., "One more child to sacrifice on the order and on the altar of open borders"; AS) and his reference to poverty (e.g., "Mothers and children trapped in poverty"; IA). This prepares the ground for him to emerge as a saviour.

(58) BAD POLITICS IS CHAINS ("We must break free from the petty politics of the past"; AS)

(59) BAD SCHOOLS ARE A DANGEROUS LOCATION ("We will rescue kids from failing schools"; AS)

Trump's image as a warrior is most evident in relation to the election campaign. While the rivalry with an opponent during election campaigns is frequently conceptualised as a belligerent strife in US politics (cf. Gibbs 2015, 265 for the metaphor of POLITICAL DEBATES ARE BOXING MATCHES), Trump verbally enhances the image when he promises to fight with "every breath in my body" (62.2).

(60) ELECTIONS ARE A WAR

60.1 "Let's defeat her in November"; AS

60.2 "We love defeating those people"; AS

(61) POLITICS IS A COMPETITION

61.1 "We don't win anymore, but we are going to start winning"; AS

61.2 "I can be your champion in the White House"; AS

(62) TRUMP IS A WARRIOR

62.1 "I will fight for you, and I will win for you"; AS

62.2 "I will fight for you with every breath in my body"; IA

Built on the source domains of WAR and COMPETITION, the metaphors in (60) and (61) are examples of the conventionalised conceptualisation of elections and politics as an extension of the ARGUMENT IS WAR metaphor proposed in Lakoff and Johnson (1980, 79-81). 


\subsection{GARdener / FARMER}

Apart from conceptualising the nation as a building, which is constitutive to his image as a constructor, some metaphors draw on the source domain of PLANT, which makes Trump appear as a gardener or farmer of the nation (63). The major lexical expression that evokes the PLANT domain is 'growth', which is also applied to the economy (64). However, the term 'growth' is highly conventionalised when talking about the economy, as in the collocation 'economic growth', which could reduce the rhetorical flagging of the metaphorical image of Trump as gardener in that context.

(63) a NATION IS A PLANT

63.1 "We will embark upon a project of national growth and renewal"; VS

63.2 "Our country will thrive and prosper again"; IA

(64) ECONOMY IS A PLANT ("We have a great economic plan. We will double our growth"; VS)

Trump employs a few more source domains from the plant frame to refer to terrorism (65), to blame the elite (66), and to denounce his opponent Clinton for supposed monetary gains (67). Particularly in (66) and (67) these metaphors are part of his positioning as one of the ordinary citizens who need to stand up against the exploitative establishment. Once more Trump uses this theme to make Clinton appear as a member of the political elite (i.e. as removed from the ordinary people).

(65) TERRORISM IS A WEED ("radical Islamic terrorism, which we will eradicate completely"; IA)

(66) MONEY ARE CROPS ("A small group in our nation's Capital has reaped the rewards of government”; IA)

(67) A LOT OF MONEY IS AN ABUNDANCE OF LEAVES ("Secretary of State rakes in millions and millions of dollars"; AS)

The metaphors that purvey the role of gardener are examples of the fact that the billionaire relies on simple and conventional language to evoke certain metaphorical themes that become constitutive of his political persona.

\subsection{Tamers of Animals}

Finally, there is another small group of metaphors that add yet a further nuance to Trump's image. In a few cases, he uses members of the ANIMAL source domain to underline his quality as a tamer of these animals. The verb 'harness', in particular, evokes the source domain of DRAFT HORSES, which is used with reference to people's talents (69) as well as to economic and technical progress (70). 
(68) COMPANIES ARE LIONS ("companies and new jobs to come roaring back into our country"; AS)

(69) TALENTS ARE DRAFT HORSES ("I will harness the creative talents of our people"; VS)

(70) ENERGIES, INDUSTRIES, AND TECHNOLOGIES ARE DRAFT HORSES ("to harness the energies, industries and technologies of tomorrow"; IA)

Ironically, the source domain of DRAFT HORSES is reminiscent of the allegorical Animal Farm by Orwell. In the novel, pigs try 'to harness' the talents of the horse Boxer. This is not for the latter's benefit, but for the financial gain of the pigs. It remains doubtful though whether Trump is aware of that intertextual reference.

\section{Final Reflections and Conclusion}

This study has examined the occurrence of conceptual metaphors in three important speeches of Trump's political career - his acceptance of the nomination, his victory speech, and his inaugural address as $45^{\text {th }}$ president of the US. All the metaphors in the speeches were elicited (see Appendix A) with the aim of exploring how they contribute to the framing of political topics and to the construction of his political persona. Considering the metaphors in general, it is striking to see that almost all instances emerge from highly conventionalised lexical expressions. This underlines Trump's plain and uncreative use of language (cf. Degani 2016) and is consistent with his self-ascribed discursive stance that he is an ordinary person ('we') that stands against the elite ('them').

In a first classification, the metaphors were categorised according to their source domains. This yields 17 different categories, from which object metaphors, personification, space and motion metaphors with its subtype of journey metaphors, building metaphors, and animal metaphors stand out as the most frequent types. Trump applies them to three major topics that are pervasive in the selected key speeches: 1) economy, business, and trade, 2) his opponents and former presidents, and 3) immigration and other nations. The latter topic of immigration is the most prevalent one, and Trump uses the conceptual metaphors of IMMIGRANTS ARE ANIMALS and IMMIGRANTS ARE A FLOOD extensively throughout his discourse. Gibbs (2015) refers to such metaphors as "extended metaphors" since they structure the entire discourse and become allegoric to the extent that they might lead to the permanent conceptualisation of a theme in the audience's minds, i.e. in Trump's case: immigrants as dangerous people and criminals. Indeed, there is not a single instance in the three speeches where this theme appears in a positive light. The conceptualisations of immigrants are always pejorative and dehumanising.

When talking about his opponents, Hillary Clinton and former presidents are frequently conceptualised as destructive forces and as being responsible for inflicting pain 
onto the nation. Business and the economy, on the other hand, are presented as a way forward for the country's future once the current state of the nation as a depleted and wounded body (in Trump's metaphorical terms) is overcome.

In addition, a range of conceptual metaphors contribute to Trump's strong focus on ethos in his speeches. By talking about himself, Trump aspires to be a charismatic leader, who will 'fix it all alone' and 'seal the country from evil and enemies' (also see Montgomery 2017). He tries to construct an image of a successful leader and worthy candidate, and conceptual metaphors point to his political persona as that of a warrior, engineer, repairman, healer, saviour, constructor, gardener, and even tamer of animals. These metaphorical personae overlap to some extent. Thus, engineer, repairman, and constructor pertain to the domain of construction which, perhaps unsurprisingly so, emerges as the most prevalent characteristic of his image as a politician. Warrior, saviour, and healer are further related facets of his self-ascribed personality, which depict him as a "Robin Hood" of the US citizens. In general, these conceptualisations share the implication of him being in control and acting upon other entities, which is very much in line with a Strict Father morality (cf. Lakoff G. 1996).

As a final note, the examples of metaphors throughout the article have made it clear that Trump's discourse is largely built on set phrases and straightforward idiomatic collocations that give rise to many conventionalised conceptual metaphors. This raises two questions which emerge as limitations of the current study. First of all, it is difficult to assess to which extent the high level of conventionalisation in both his language and the underlying conceptual metaphors triggers the rhetorical effects that have emerged from the close analysis of his speeches. Secondly, this investigation only focussed on conceptual metaphors and how they contributed to Trump's discussion of political topics and to the construction of his political persona. A comprehensive analysis taking into account other rhetorical strategies as well would give a more complete picture of Trump's discursive practices.

\section{References}

Bougher, Lori D. 2012. "The case of metaphors in political reasoning and cognition". Political Psychology 33 (1): 145-163.

Charteris-Black, Jonathan. 2006. "Britain as a container: Immigration metaphors in the 2005 election campaign.” Discourse E Society 17 (5): 563-581.

Charteris-Black, Jonathan. 2012. "Forensic deliberation on 'purposeful metaphor". Metaphor and the Social World 2 (1): 1-21.

Chilton, Paul. 2004. Analyzing political discourse. London: Routledge.

Chilton, Paul. 2017. “'The people' in populist discourse. Using neuro-cognitive linguistics to understand political meanings". Journal of Language and Politics 16 (4): 582-594.

Cienki, Alan. 2005. "Metaphor in the 'strict father' and 'nurturant parent' cognitive models: Theoretical issues raised in an empirical study”. Cognitive Linguistics 16 (2): 279-312. 
Degani, Marta, 2015. Framing the Rhetoric of a Leader: An Analysis of Obama's Election Campaign Speeches. Basingstoke: Palgrave Macmillan.

Degani, Marta. 2016. "Endangered intellect: A case study of Clinton vs Trump campaign discourse”. Iperstoria 8: 131-145.

De Landtsheer, Christ'l, Philippe De Vries \& Dieter Vertessen. 2008. "Political impression management: How metaphors, sound bites, appearance effectiveness, and personality traits can win elections". Journal of Political Marketing 7 (3-4): 217-238.

Demata, Massimiliano. 2017. “'A great and beautiful wall.' Donald Trump's populist discourse on immigration." Journal of Language Aggression and Conflict 5 (2): 274-294.

Edelman, Murray. 1964. The Symbolic Uses of Politics. Urbana: University of Illinois Press.

Ezrahi, Yaron. 1995. "The theatrics and mechanics of action: The theater and the machine as political metaphors”. Social Research 62 (2): 299-322.

Ferrari, Federica. 2007. "Metaphor at work in the analysis of political discourse: Investigating a 'preventive war' persuasion strategy”. Discourse E Society 18 (5): 603 - 625.

Gibbs, Raymond W. Jr. 2015. “The allegorical character of political metaphors in discourse”. Metaphor and the Social World 5 (2): 264-282.

Johnson, Paul E. 2017. “The art of masculine victimhood: Donald Trump's demagoguery”. Women's Studies in Communication 40 (3): 229-250.

Kreis, Ramona. 2017. “\#refugeesnotwelcome: Anti-refugee discourse on Twitter”. Discourse $\mathcal{E}$ Communication 11(5): 498-514.

Lakoff, George. 1996. Moral politics: What Conservatives know that Liberals don't. Chicago: University of Chicago Press.

Lakoff, George \& Mark Johnson. 1980. Metaphors We Live by. Chicago, IL: University of Chicago Press.

Lakoff, George \& Mark Turner. 1989. More Than Cool Reason: A Field Guide to Poetic Metaphor. Chicago \& London: The University of Chicago Press.

Lakoff, Robin T. 2017. "The hollow man. Donald Trump, populism, and post-truth politics". Journal of Language and Politics 16 (4): 595-606.

Lau, Richard R., \& David P. Redlawsk. 2001. "Advantages and disadvantages of cognitive heuristics in political decision making”. Journal of Political Science 45 (4): 951-971.

Martin, James. 2013. Politics and rhetoric: A critical introduction. London: Routledge.

Mio, Jeffery S. 1997. "Metaphor and politics". Metaphor and Symbol 12 (2): 113-133.

Montgomery, Martin. 2017. "Post-truth politics? Authenticity, populism and the electoral discourses of Donald Trump". Journal of Language and Politics 16 (4): 619-639.

Musolff, Andreas. 2010. Metaphor, Nation and Holocaust: The Concept of the Body Politic. London $\&$ New York: Routledge.

Oliver, Eric J., \& Wendy M. Rahn. 2016. "Rise of the Trumpenvolk: Populism in the 2016 election". The Annals of the American Academy 667: 189-206.

Pawelec, Andrzej. 2006. “The death of metaphor”. Studia Linguistica 123: 117-122.

Pragglejaz Group. 2007. "MIP: A method for identifying metaphorically used words in discourse". Metaphor and Symbol 22 (1): 1-39.

Santa Ana, Otto. 1999. “Like an animal I was treated': Anti-immigrant metaphor in US public discourse”. Discourse E Society 10 (2): 191-224. 
Shafer, Jessica G. 2017. “Donald Trump’s 'political incorrectness': Neoliberalism as frontstage racism on social media”. Social Media + Society, July-September: 1-10. doi: 10.1177/205630511 7733226

Schoor, Carola. 2015. "Political metaphor, a matter of purposeful style. On the rational, emotional and strategic purposes of political metaphor". Metaphor and the Social World 5 (1): 82-101.

Steen, J. Gerard. 2007. "Finding metaphor in discourse: Pragglejaz and beyond". Culture, Language and Representation 5: 9-25.

Stone, Deborah A. 1988. Policy paradox and political reason. Glenview: IL: Scott, Foresman. Van Dijk, Teun, A. 2006. Discourse and manipulation. Discourse E Society 17 (3): 359-383. Van Dijk, Teun A. 1998. Ideology: A multidisciplinary approach. Newbury Park, CA: Sage.

Wodak, Ruth. 2015. The politics of fear: What right-wing populist discourses mean. London: SAGE Publications.

\section{Primary data}

"Victory speech". CNN. 9 Nov. 2016.

Accessed at http://edition.cnn.com/2016/11/09/politics/donald-trump-victory-speech/ "Inaugural Address" CNN. 21 Jan. 2017.

Accessed at http://edition.cnn.com/2017/01/20/politics/trump-inaugural-address/.

"Address accepting the presidential nomination".

Accessed at http://www.presidency.ucsb.edu/ws/index.php?pid=117935 


\section{Appendix A}

\section{Metaphor Frequency}

Total Number: 346 metaphors;

Unique Metaphors: 235 metaphors (67.9\%)

\begin{tabular}{lrrr}
\hline Speech & Number of metaphors & Number of words & Metaphor frequency in speech \\
\hline \hline Acceptance speech & 211 & 5,114 & 1 metaphor per 24.2 words (4.13\%) \\
Victory speech & 65 & 1,617 & 1 metaphor per 24.9 words (4,02\%) \\
Inauguration speech & 70 & 1,444 & 1 metaphor per 20.63 words (4.85\%) \\
\hline
\end{tabular}

\section{Basic Frequency Findings}

\begin{tabular}{|c|c|c|c|c|c|}
\hline \# & Metaphor & $\begin{array}{r}\text { Total } \\
\text { number }\end{array}$ & $\begin{array}{r}\text { Acceptance } \\
\text { speech }\end{array}$ & $\begin{array}{r}\text { Victory } \\
\text { speech }\end{array}$ & $\begin{array}{r}\text { Inauguration } \\
\text { speech }\end{array}$ \\
\hline \multirow{2}{*}{\multicolumn{2}{|c|}{ Person Metaphors }} & 57 & 27 & 8 & 22 \\
\hline & & $(16.47 \%)$ & & & \\
\hline 1. & A NATION IS A PERSON & 26 & 12 & 5 & 9 \\
\hline 2. & POLITICIANS ARE SERVANTS & 3 & 1 & 2 & 0 \\
\hline 3. & HISTORY IS A PERSON & 2 & 2 & 0 & 0 \\
\hline 4. & THE MILITARY IS A PERSON & 2 & 1 & 0 & 1 \\
\hline 5. & A PLANET IS A PERSON & 2 & 0 & 0 & 2 \\
\hline 6. & A TRADE DEAL IS AN IMMORAL PERSON & 2 & 2 & 0 & 0 \\
\hline 7. & OTHER NATIONS ARE THIEVES & 2 & 0 & 0 & 2 \\
\hline 8. & A NATION IS A THIEF & 1 & 1 & 0 & 0 \\
\hline 9. & A POLITICAL SYSTEM IS A PERSON & 1 & 1 & 0 & 0 \\
\hline 10. & A POLICY IS A PERSON & 1 & 1 & 0 & 0 \\
\hline 11. & ECONOMY IS A PERSON & 1 & 0 & 1 & 0 \\
\hline 12. & A TRADE DEAL IS A MURDERER & 1 & 1 & 0 & 0 \\
\hline 13. & LAWS ARE PEOPLE & 1 & 1 & 0 & 0 \\
\hline 14. & JOBS ARE PEOPLE & 1 & 1 & 0 & 0 \\
\hline 15. & BUILDINGS ARE PEOPLE & 1 & 0 & 0 & 1 \\
\hline 16. & ALLIES ARE FAMILY RELATIONS & 1 & 1 & 0 & 0 \\
\hline 17. & PATRIOTISM IS A DOCTOR & 1 & 0 & 0 & 1 \\
\hline 18. & PATRIOTISM IS A VISITOR & 1 & 0 & 0 & 1 \\
\hline 19. & A PRESIDENT IS A PREACHER & 1 & 1 & 0 & 0 \\
\hline 20. & THE MILITARY PERSONNEL ARE SERVANTS & 1 & 1 & 0 & 0 \\
\hline
\end{tabular}




\begin{tabular}{llrrrr}
\hline$\#$ & Metaphor & Total & Acceptance & Victory & Inauguration \\
speech & number & speech & speech \\
\hline \hline
\end{tabular}

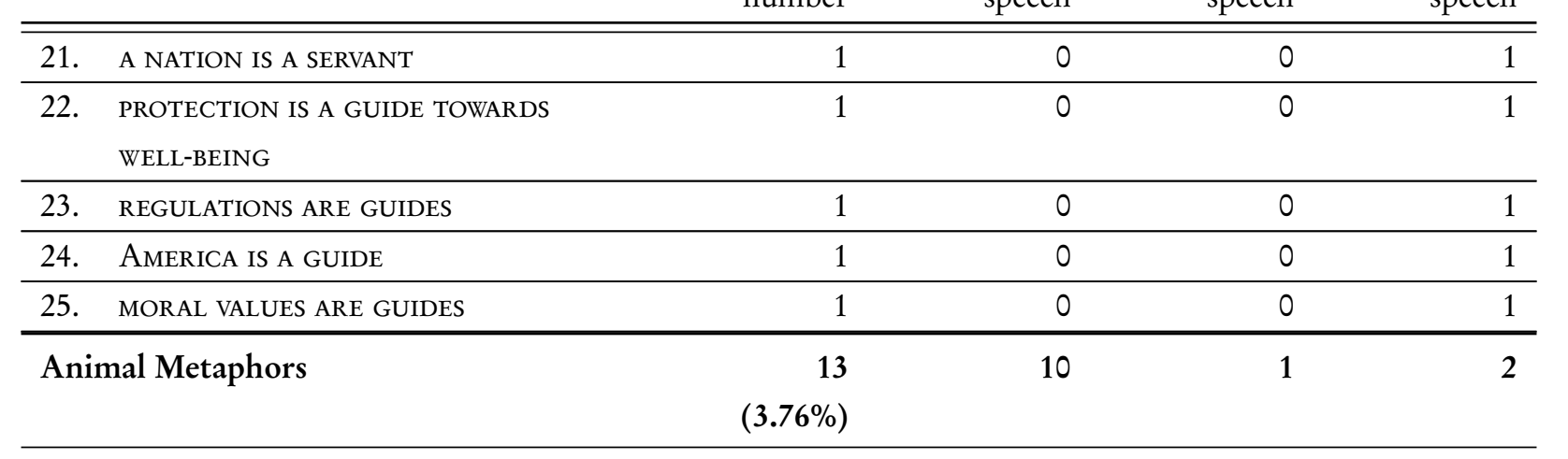

\begin{tabular}{llllll}
\hline 1. & IMMIGRANTS ARE ANIMALS & 4 & 4 & 0 & 0 \\
\hline 2. & PEOPLE ARE ANIMALS & 1 & 0 & 0 & 0 \\
\hline 3. & TERRORISM IS AN ANIMAL & 1 & 1 & 1 & 0 \\
\hline 4. & A TERRORIST IS AN ANIMAL & 1 & 1 & 0 & 0 \\
\hline 5. & TERRORISTS ARE INSECTS & 1 & 1 & 0 & 0
\end{tabular}
TO AN ANIMAL

\begin{tabular}{llllll}
\hline 7. & CLINTON IS A PIG & 1 & 1 & 0 & 0 \\
\hline 8. & COMPANIES ARE LIONS & 1 & 1 & 0 & 0 \\
\hline 9. & TALENTS ARE DRAFT HORSES & 1 & 0 & 1 & 0 \\
\hline 10. & ENERGIES, INDUSTRIES, AND & 1 & 0 & 0 & 1
\end{tabular}
TECHNOLOGIES ARE DRAFT HORSES

\begin{tabular}{lrrrr}
\hline Object Metaphors & 65 & 40 & 21 & 4 \\
\hline
\end{tabular}

\begin{tabular}{llllll}
\hline 1. & AN OATH IS AN OBJECT & 5 & 4 & 1 & 0 \\
\hline 2. & PEOPLE ARE OBJECTS & 4 & 2 & 2 & 0 \\
\hline 3. & POLITICAL POWER IS AN OBJECT & 4 & 0 & 4 & 0 \\
\hline 4. & A NATION IS AN OBJECT & 3 & 3 & 0 & 0 \\
\hline 5. & A JOB IS AN OBJECT & 3 & 2 & 1 & 0 \\
\hline 6. & SUPPORT IS AN OBJECT & 2 & 2 & 2 & 0 \\
\hline 7. & TIME IS AN OBJECT & 2 & 0 & 0 \\
\hline 8. & LOVE IS AN OBJECT & 2 & 2 & 0 & 0 \\
\hline 9. & A DREAM IS AN OBJECT & 2 & 0 & 0 & 0 \\
\hline 10. & CONTROL IS AN OBJECT & 1 & 1 & 0 & 0 \\
\hline 11. & A PLAN IS AN OBJECT & 1 & 1 & 0 & 0 \\
\hline 12. & E-MAILS ARE OBJECTS & 1 & 1 & 0 & 0 \\
\hline 13. & SECRETS ARE OBJECTS & 1 & 1 & 0 & 0 \\
\hline 14. & SUCCESS IS AN OBJECT & 1 & 1 & 0 & 0 \\
\hline
\end{tabular}




\begin{tabular}{|c|c|c|c|c|c|}
\hline$\#$ & Metaphor & $\begin{array}{r}\text { Total } \\
\text { number }\end{array}$ & $\begin{array}{r}\text { Acceptance } \\
\text { speech }\end{array}$ & $\begin{array}{r}\text { Victory } \\
\text { speech }\end{array}$ & $\begin{array}{r}\text { Inauguration } \\
\text { speech }\end{array}$ \\
\hline 15. & ACTIONS ARE OBJECTS & 1 & 1 & 0 & 0 \\
\hline 16. & POLICY IS AN OBJECT & 1 & 1 & 0 & 0 \\
\hline 17. & GOALS ARE OBJECTS & 1 & 1 & 0 & 0 \\
\hline 18. & EXPENDITURE IS AN OBJECT & 1 & 1 & 0 & 0 \\
\hline 19. & PAIN IS AN OBJECT & 1 & 1 & 0 & 0 \\
\hline 20. & RESPECT IS AN OBJECT & 1 & 1 & 0 & 0 \\
\hline 21. & VOICE IS AN OBJECT & 1 & 1 & 0 & 0 \\
\hline 22. & VICTORY IS AN OBJECT & 1 & 1 & 0 & 0 \\
\hline 23. & GUIDANCE AND HELP IS AN OBJECT & 1 & 0 & 1 & 0 \\
\hline 24. & A MOVEMENT IS AN OBJECT & 1 & 0 & 1 & 0 \\
\hline 25. & CHALLENGE IS AN OBJECT & 1 & 0 & 1 & 0 \\
\hline 26. & GRATITUDE IS AN OBJECT & 1 & 0 & 1 & 0 \\
\hline 27. & DESTINY IS AN OBJECT & 1 & 0 & 0 & 1 \\
\hline 28. & WEALTH IS AN OBJECT & 1 & 0 & 1 & 0 \\
\hline 29. & PREJUDICE IS AN OBJECT & 1 & 0 & 1 & 0 \\
\hline 30. & AN ELECTION CAMPAIGN IS AN OBJECT & 1 & 1 & 0 & 0 \\
\hline 31. & A TALENT IS AN OBJECT & 1 & 0 & 1 & 0 \\
\hline 32. & CRIME AND VIOLENCE IS A MOVING OBJECT & 1 & 1 & 0 & 0 \\
\hline 33. & A CONVENTION IS AN OBJECT & 1 & 1 & 0 & 0 \\
\hline 34. & A NOMINATION IS AN OBJECT & 1 & 1 & 0 & 0 \\
\hline 35. & IDEAS ARE POSSESSIONS & 1 & 1 & 0 & 0 \\
\hline 36. & LIFE IS A VALUABLE POSSESSION & 1 & 0 & 1 & 0 \\
\hline 37. & SOLIDARITY IS AN OBJECT TO BE PURSUED & 1 & 0 & 0 & 1 \\
\hline 38. & POVERTY IS A TRAP & 1 & 0 & 0 & 1 \\
\hline 39. & BAD POLITICS IS CHAINS & 1 & 1 & 0 & 0 \\
\hline 40. & PEOPLE ARE LINKS OF A CHAIN & 1 & 0 & 0 & 1 \\
\hline 41. & PROBLEMS ARE FABRIC & 1 & 1 & 0 & 0 \\
\hline 42. & FAMILIES ARE FABRIC & 1 & 1 & 0 & 0 \\
\hline 43. & WEALTH IS A FABRIC & 1 & 0 & 1 & 0 \\
\hline 44. & $\begin{array}{l}\text { POLITICAL CORRECTNESS IS AN EXPENSIVE } \\
\text { ITEM }\end{array}$ & 1 & 1 & 0 & 0 \\
\hline 45. & $\begin{array}{l}\text { LIES ARE SKILLFULLY MANUFACTURED } \\
\text { GOODS }\end{array}$ & 1 & 1 & 0 & 0 \\
\hline 46. & RESULTS ARE PRODUCTS & 1 & 1 & 0 & 0 \\
\hline 47. & $\begin{array}{l}\text { WAGES AND UNEMPLOYMENT ARE } \\
\text { PRODUCTS }\end{array}$ & 1 & 1 & 0 & 0 \\
\hline
\end{tabular}




\begin{tabular}{|c|c|c|c|c|c|}
\hline$\#$ & Metaphor & $\begin{array}{l}\text { Total } \\
\text { number }\end{array}$ & $\begin{array}{r}\text { Acceptance } \\
\text { speech }\end{array}$ & $\begin{array}{r}\text { Victory } \\
\text { speech }\end{array}$ & $\begin{array}{r}\text { Inauguration } \\
\text { speech }\end{array}$ \\
\hline \multicolumn{2}{|c|}{ Physical Suffering Metaphors } & $9(2.6 \%)$ & 5 & 1 & 3 \\
\hline 1. & SOCIAL DIVISION IS A WOUND & 2 & 0 & 1 & 1 \\
\hline 2. & IMMIGRATION IS PAIN & 1 & 1 & 0 & 0 \\
\hline 3. & $\begin{array}{l}\text { EMOTIONAL SUFFERING IS A PHYSICAL } \\
\text { WOUND }\end{array}$ & 1 & 1 & 0 & 0 \\
\hline 4. & PROBLEMS ARE PHYSICAL SUFFERING & 1 & 0 & 0 & 1 \\
\hline 5. & FINANCIAL LOSS IS BLEEDING & 1 & 0 & 0 & 1 \\
\hline 6. & CRIME AND VIOLENCE IS A DISEASE & 1 & 1 & 0 & 0 \\
\hline 7. & BAD AGREEMENTS ARE PAIN & 1 & 1 & 0 & 0 \\
\hline 8. & TAXES ARE PAIN & 1 & 1 & 0 & 0 \\
\hline \multicolumn{2}{|c|}{ Force Metaphors } & $\begin{array}{r}16 \\
(4.62 \%) \\
\end{array}$ & 13 & 0 & 3 \\
\hline 1. & DIFFICULTIES ARE OPPOSING FORCES & 4 & 2 & 0 & 2 \\
\hline 2. & RESISTANCE IS REMAINING UPRIGHT & 2 & 2 & 0 & 0 \\
\hline 3. & A PROBLEM IS A DESTRUCTIVE FORCE & 1 & 2 & 0 & 0 \\
\hline 4. & IMMIGRANTS ARE A DESTRUCTIVE FORCE & 1 & 1 & 0 & 0 \\
\hline 5. & A TRADE DEAL IS A DESTRUCTIVE FORCE & 1 & 1 & 0 & 0 \\
\hline 6. & A MISTAKE IS A DESTRUCTIVE FORCE & 2 & 1 & 0 & 0 \\
\hline 7. & OBAMACARE IS A DESTRUCTIVE FORCE & 1 & 1 & 0 & 0 \\
\hline 8. & $\begin{array}{l}\text { TRANSPORTATION SECURITY } \\
\text { ADMINISTRATION IS A DESTRUCTIVE FORCE }\end{array}$ & 1 & 1 & 0 & 0 \\
\hline 9. & $\begin{array}{l}\text { CURRENCY MANIPULATION IS A } \\
\text { DEVASTATING FORCE }\end{array}$ & 1 & 1 & 0 & 0 \\
\hline 10. & PATRIOTISM IS A FORCE & 1 & 0 & 0 & 1 \\
\hline 11. & AUTHORITY IS PHYSICAL POWER & 1 & 1 & 0 & 0 \\
\hline \multicolumn{2}{|c|}{ Building Metaphors } & $\begin{array}{r}24 \\
(6.94 \%) \\
\end{array}$ & 16 & 2 & 6 \\
\hline 1. & A NATION IS A BUILDING & 5 & 2 & 1 & 2 \\
\hline 2. & PEACE IS STABILITY & 2 & 2 & 0 & 0 \\
\hline 3. & PEACE IS A BUILDING & 1 & 1 & 0 & 0 \\
\hline 4. & SAFETY IS A BUILDING & 1 & 1 & 0 & 0 \\
\hline 5. & CRIME IS A BUILDING & 1 & 1 & 0 & 0 \\
\hline 6. & THE WORLD IS A BUILDING & 1 & 1 & 0 & 0 \\
\hline 7. & COMMUNITIES ARE BUILDINGS & 1 & 1 & 0 & 0 \\
\hline 8. & LAW AND ORDER IS A BUILDING & 1 & 1 & 0 & 0 \\
\hline 9. & LIFE IS A BUILDING & 1 & 1 & 0 & 0 \\
\hline
\end{tabular}




\begin{tabular}{|c|c|c|c|c|c|}
\hline$\#$ & Metaphor & $\begin{array}{l}\text { Total } \\
\text { number }\end{array}$ & $\begin{array}{r}\text { Acceptance } \\
\text { speech }\end{array}$ & $\begin{array}{r}\text { Victory } \\
\text { speech }\end{array}$ & $\begin{array}{r}\text { Inauguration } \\
\text { speech }\end{array}$ \\
\hline 10. & ISIS IS A BUILDING & 1 & 1 & 0 & 0 \\
\hline 11. & SOCIAL CLASS IS A BUILDING & 1 & 1 & 0 & 0 \\
\hline 12. & TRANSACTION IS A BUILDING & 1 & 1 & 0 & 0 \\
\hline 13. & THE MILITARY IS A BUILDING & 1 & 1 & 0 & 0 \\
\hline 14. & A MOVEMENT IS A BUILDING & 1 & 0 & 1 & 0 \\
\hline 15. & DESOLATION IS A RUSTED BUILDING & 1 & 0 & 0 & 1 \\
\hline 16. & A PROMISE IS A BUILDING & 1 & 0 & 0 & 1 \\
\hline 17. & POLITICS IS A BUILDING & 1 & 0 & 0 & 1 \\
\hline 18. & HEART IS A HOME & 1 & 0 & 0 & 1 \\
\hline 19. & BORDERS ARE DOORS TO A BUILDING & 1 & 1 & 0 & 0 \\
\hline \multicolumn{2}{|c|}{ Container Metaphors } & $8(2.31 \%)$ & 4 & 0 & 4 \\
\hline 1. & A COUNTRY IS A CONTAINER & 2 & 2 & 0 & 0 \\
\hline 2. & COMMUNITIES ARE CONTAINERS & 1 & 1 & 0 & 0 \\
\hline 3. & POVERTY IS A CONTAINER & 1 & 1 & 0 & 0 \\
\hline 4. & MEANING IS SUBSTANCE IN A CONTAINER & 1 & 0 & 0 & 1 \\
\hline 5. & THE HEART IS A CONTAINER & 1 & 0 & 0 & 1 \\
\hline 6. & PEOPLE ARE CONTAINERS & 1 & 0 & 0 & 1 \\
\hline 7. & $\begin{array}{l}\text { THE UNKNOWN IS THE CONTENTS OF A } \\
\text { LOCKED CHEST }\end{array}$ & 1 & 0 & 0 & 1 \\
\hline \multicolumn{2}{|c|}{ Machine Metaphors } & $8(2.31 \%)$ & 8 & 0 & 0 \\
\hline 1. & SOLVING PROBLEMS IS FIXING A MACHINE & 5 & 5 & 0 & 0 \\
\hline 2. & THE POLITICAL SYSTEM IS A MACHINE & 1 & 1 & 0 & 0 \\
\hline 3. & $\begin{array}{l}\text { TRANSPORTATION SECURITY } \\
\text { ADMINISTRATION IS A MACHINE }\end{array}$ & 1 & 1 & 0 & 0 \\
\hline 4. & IMMIGRATION IS A MACHINE & 1 & 1 & 0 & 0 \\
\hline \multicolumn{2}{|c|}{ Motion and Journey Metaphors } & $\begin{array}{r}23 \\
(6.64 \%) \\
\end{array}$ & 17 & 2 & 4 \\
\hline 1. & CHANGE IS MOTION & 8 & 5 & 1 & 2 \\
\hline 2. & TIME IS MOTION & 3 & 2 & 0 & 1 \\
\hline 3. & $\begin{array}{l}\text { A CHARACTERISTIC IS A PARTICULAR } \\
\text { ROTATION }\end{array}$ & 1 & 1 & 0 & 0 \\
\hline 4. & $\begin{array}{l}\text { REACHING A GOAL IS MOTION ALONG A } \\
\text { PATH TOWARDS A DESTINATION }\end{array}$ & 1 & 1 & 0 & 0 \\
\hline 5. & TIME IS A MOVING VEHICLE & 1 & 1 & 0 & 0 \\
\hline 6. & REFUSING IS GOING AWAY & 1 & 1 & 0 & 0 \\
\hline 7. & DAMAGE IS FALLING & 1 & 0 & 0 & 1 \\
\hline
\end{tabular}




\begin{tabular}{|c|c|c|c|c|c|}
\hline \# & Metaphor & $\begin{array}{r}\text { Total } \\
\text { number }\end{array}$ & $\begin{array}{r}\text { Acceptance } \\
\text { speech }\end{array}$ & $\begin{array}{r}\text { Victory } \\
\text { speech }\end{array}$ & $\begin{array}{r}\text { Inauguration } \\
\text { speech }\end{array}$ \\
\hline
\end{tabular}

\begin{tabular}{llllll}
\hline \hline 8. & LIFE IS A JOURNEY & 3 & 3 & 0 & 0 \\
\hline 9. & AN ELECTION CAMPAIGN IS A JOURNEY & 2 & 2 & 1 & 0 \\
\hline $\begin{array}{l}\text { 10. } \\
\quad \begin{array}{l}\text { HUMAN SMUGGLING AND VIOLENCE IS A } \\
\text { (NEVE-ENDING) JOURNEY }\end{array}\end{array}$ & 1 & 1 & 0 & 0 \\
\hline $\begin{array}{l}\text { POVERTY IS A (NEVER-ENDING) JOURNEY } \\
\text { Spatial Metaphors }\end{array}$ & 1 & 1 & $\mathbf{0}$ & 0 \\
\hline
\end{tabular}

$(8.96 \%)$

\begin{tabular}{llllll}
\hline 1. & SUPPORT IS PROXIMITY & 4 & 4 & 0 & 0 \\
\hline 2. & MORE IS UP & 3 & 3 & 1 & 0 \\
\hline 3. & DISAPPOINTMENT IS DOWN & 2 & 0 & 1 & 1 \\
\hline 4. & FUTURE IS AHEAD & 2 & 0 & 0 & 0 \\
\hline 5. & STRONG IS UP & 1 & 1 & 1 & 0 \\
\hline 6. & SUPPORTING IS LIFTING UP & 1 & 0 & 1 & 0 \\
\hline 7. & HEAVEN IS UP & 1 & 0 & 0 & 0 \\
\hline 8. & HONOR IS UP & 1 & 0 & 0 & 0 \\
\hline 9. & GOOD IS UP & 1 & 1 & 0 & 0 \\
\hline 10. & LESS IS DOWN & 1 & 1 & 1 & 0 \\
\hline 11. & HUMILIATION IS DOWN & 1 & 1 & 1 & 0 \\
\hline 12. & ATTENTION IS PROXIMITY & 1 & 1 & 0 & 0
\end{tabular}

LOCATIONS

\begin{tabular}{llllll}
\hline 16. & BAD SCHOOLS ARE A DANGEROUS LOCATION & 1 & 1 & 0 & 0 \\
\hline 17. & AGREEING IS SETTLING AT A LOCATION & 1 & 0 & 1 & 0 \\
\hline 18. & LOYALTY IS A LOCATION & 1 & 0 & 1 & 0 \\
\hline 19. & TIME IS SPACE & 1 & 0 & 1 & 0 \\
\hline 20. & DUTY IS AN ORDERLY SPATIAL & 1 & 1 & 0
\end{tabular}

ARRANGEMENT

\begin{tabular}{llllll}
\hline 21. & EMOTIONAL INTENSITY IS DEPTH & 1 & 1 & 0 & 0 \\
\hline 22. & IMPORTANT IS CENTRAL & 1 & 0 & 0 & 1 \\
\hline 23. & $\begin{array}{l}\text { REDUCING THE PRICE OF A PRODUCT IS } \\
\text { DECREASING VERTICAL ELEVATION }\end{array}$ & 1 & 1 & 0 & 0 \\
\hline $24 . \quad$ INCREASE IN QUANTITY IS INCREASE IN SIZE & 1 & 0 & 1 & 0 \\
\hline Plant Metaphors & $\mathbf{9 ( 2 . 6 \% )}$ & $\mathbf{2}$ & $\mathbf{2}$ & $\mathbf{5}$ \\
\hline 1. & A NATION IS A PLANT & 2 & 0 & 1 & 1 \\
\hline
\end{tabular}




\begin{tabular}{|c|c|c|c|c|c|}
\hline$\#$ & Metaphor & $\begin{array}{l}\text { Total } \\
\text { number }\end{array}$ & $\begin{array}{r}\text { Acceptance } \\
\text { speech }\end{array}$ & $\begin{array}{r}\text { Victory } \\
\text { speech }\end{array}$ & $\begin{array}{r}\text { Inauguration } \\
\text { speech }\end{array}$ \\
\hline 2. & A CITY IS A PLANT & 2 & 0 & 0 & 2 \\
\hline 3. & ECONOMY IS A PLANT & 1 & 0 & 1 & 0 \\
\hline 4. & MONEY ARE CROPS & 1 & 0 & 0 & 1 \\
\hline 5. & TERRORISM IS A WEED & 1 & 0 & 0 & 1 \\
\hline 6. & $\begin{array}{l}\text { A LOT OF MONEY IS AN ABUNDANCE OF } \\
\text { LEAVES }\end{array}$ & 1 & 1 & 0 & 0 \\
\hline 7. & KILLING IS CUTTING DOWN GRASS & 1 & 1 & 0 & 0 \\
\hline \multicolumn{2}{|c|}{ Money Metaphors } & $6(1.7 \%)$ & 2 & 4 & 0 \\
\hline 1. & TIME IS MONEY & 3 & 1 & 2 & 0 \\
\hline 2. & GRATITUDE IS MONEY & 1 & 0 & 1 & 0 \\
\hline 3. & $\begin{array}{l}\text { PUNISHMENT IS PAYING EXCESSIVE } \\
\text { AMOUNTS OF MONEY }\end{array}$ & 1 & 1 & 0 & 0 \\
\hline 4. & PERSONAL RELATIONS ARE BUSINESS & 1 & 0 & 1 & 0 \\
\hline \multicolumn{2}{|c|}{ Liquid Metaphors } & $\begin{array}{r}12 \\
(3.47 \%)\end{array}$ & 7 & 2 & 3 \\
\hline 1. & $\begin{array}{l}\text { DRUGS ARE AN UNCONTAINED FLOW OF } \\
\text { WATER }\end{array}$ & 1 & 1 & 0 & 0 \\
\hline 2. & MONEY IS FLOWING WATER & 1 & 1 & 0 & 0 \\
\hline 3. & MONEY IS WATER & 1 & 0 & 0 & 1 \\
\hline 4. & WAR IS A FLOOD & 1 & 1 & 0 & 0 \\
\hline 5. & IMMIGRATION IS A FLOOD & 1 & 1 & 0 & 0 \\
\hline 6. & DEBTS ARE A DEADLY FLOOD & 1 & 1 & 0 & 0 \\
\hline 7. & VIOLENCE IS AN OVERFLOWING LIQUID & 1 & 1 & 0 & 0 \\
\hline 8. & SOUL IS A LIQUID & 1 & 0 & 0 & 1 \\
\hline 9. & POTENTIAL IS A LIQUID & 1 & 0 & 1 & 0 \\
\hline 10. & PRIDE AND JOY ARE LIQUIDS & 1 & 0 & 1 & 0 \\
\hline 11. & A SCANDAL IS A SUBSTANCE & 1 & 1 & 0 & 0 \\
\hline 12. & MEANING IS SUBSTANCE IN A CONTAINER & 1 & 0 & 0 & 1 \\
\hline \multicolumn{2}{|c|}{ Competition Metaphors } & $\begin{array}{r}15 \\
(4.34 \%)\end{array}$ & 8 & 5 & 2 \\
\hline 1. & ELECTIONS ARE A COMPETITION & 4 & 2 & 2 & 0 \\
\hline 2. & ELECTIONS ARE A WAR & 2 & 2 & 0 & 0 \\
\hline 3. & TRUMP IS A WARRIOR & 2 & 1 & 0 & 1 \\
\hline 4. & ELECTIONS ARE FIGHTS & 2 & 0 & 2 & 0 \\
\hline 5. & POLITICS IS A COMPETITION & 2 & 2 & 0 & 0 \\
\hline 6. & AN ELECTION CAMPAIGN IS A HORSERACE & 1 & 0 & 1 & 0 \\
\hline
\end{tabular}




\begin{tabular}{|c|c|c|c|c|c|}
\hline$\#$ & Metaphor & $\begin{array}{r}\text { Total } \\
\text { number }\end{array}$ & $\begin{array}{r}\text { Acceptance } \\
\text { speech }\end{array}$ & $\begin{array}{r}\text { Victory } \\
\text { speech }\end{array}$ & $\begin{array}{r}\text { Inauguration } \\
\text { speech }\end{array}$ \\
\hline 7. & DEALING WITH PROBLEMS IS FIGHTING & 1 & 1 & 0 & 0 \\
\hline 8. & DEALING WITH POVERTY IS FIGHTING & 1 & 0 & 0 & 1 \\
\hline \multicolumn{2}{|c|}{ Seeing Metaphors } & $8(2.31 \%)$ & 7 & 0 & 1 \\
\hline 1. & $\begin{array}{l}\text { BEING CONFRONTED WITH STHG. IS } \\
\text { LOOKING AT STHG. }\end{array}$ & 3 & 3 & 0 & 0 \\
\hline 2. & BELIEVING IS SEEING & 2 & 2 & 0 & 0 \\
\hline 3. & HAVING A PLAN IS SEEING & 1 & 1 & 0 & 0 \\
\hline 4. & $\begin{array}{l}\text { IGNORING A PROBLEM IS INTENTIONALLY } \\
\text { NOT SEEING }\end{array}$ & 1 & 1 & 0 & 0 \\
\hline 5. & LOSING IS MOVING OUT OF SIGHT & 1 & 0 & 0 & 1 \\
\hline \multicolumn{2}{|c|}{ Holding Metaphors } & $5(1.45 \%)$ & 3 & 2 & 0 \\
\hline 1. & UNDERSTANDING IS HOLDING & 2 & 2 & 0 & 0 \\
\hline 2. & POSSESSION IS HOLDING & 2 & 0 & 2 & 0 \\
\hline 3. & $\begin{array}{l}\text { ENFORCING LEGISLATION IS HOLDING UP } \\
\text { AN OBJECT }\end{array}$ & 1 & 1 & 0 & 0 \\
\hline \multicolumn{2}{|c|}{ Other Metaphors } & $\begin{array}{r}37 \\
(10.7 \%)\end{array}$ & 26 & 4 & 7 \\
\hline 1. & $\begin{array}{l}\text { TWO DIFFERENT OPINIONS ARE TWO HANDS } \\
\text { OF THE BODY }\end{array}$ & 3 & 3 & 0 & 0 \\
\hline 2. & BEING THE BEST IS BEING FIRST & 2 & 2 & 0 & 0 \\
\hline 3. & REFORMS ARE DRAWINGS & 2 & 2 & 0 & 0 \\
\hline 4. & GOOD IS LIGHT & 2 & 0 & 1 & 1 \\
\hline 5. & INTELLIGENT IS BRIGHT & 2 & 1 & 1 & 0 \\
\hline 6. & TRUTH IS PLAIN & 2 & 2 & 0 & 0 \\
\hline 7. & $\begin{array}{l}\text { A CHARACTERISTIC MESSAGE IS A } \\
\text { SIGNATURE }\end{array}$ & 1 & 1 & 0 & 0 \\
\hline 8. & $\begin{array}{l}\text { A CHARACTERISTIC FEATURE IS A } \\
\text { SIGNATURE }\end{array}$ & 1 & 1 & 0 & 0 \\
\hline 9. & INTELLIGENT IS SHARP & 1 & 0 & 1 & 0 \\
\hline 10. & BEING UNDER CONTROL IS BEING A PUPPET & 1 & 1 & 0 & 0 \\
\hline 11. & $\begin{array}{l}\text { MANIPULATING IS PULLING STRINGS OF A } \\
\text { PUPPET }\end{array}$ & 1 & 1 & 0 & 0 \\
\hline 12. & $\begin{array}{l}\text { LOSING JOBS AND WEALTH IS BECOMING } \\
\text { NAKED }\end{array}$ & 1 & 1 & 0 & 0 \\
\hline 13. & DESTROYING JOBS IS BURNING & 1 & 1 & 0 & 0 \\
\hline 14. & EXISTENCE IS BEING ON A MAP & 1 & 1 & 0 & 0 \\
\hline
\end{tabular}




\begin{tabular}{|c|c|c|c|c|c|}
\hline \# & Metaphor & $\begin{array}{r}\text { Total } \\
\text { number }\end{array}$ & $\begin{array}{r}\text { Acceptance } \\
\text { speech }\end{array}$ & $\begin{array}{r}\text { Victory } \\
\text { speech }\end{array}$ & $\begin{array}{r}\text { Inauguration } \\
\text { speech }\end{array}$ \\
\hline 15. & INFLUENCE IS VOICE & 1 & 1 & 0 & 0 \\
\hline 16. & PROJECTS ARE SHIPS & 1 & 0 & 1 & 0 \\
\hline 17. & AMERICA IS A SHIP & 1 & 0 & 0 & 1 \\
\hline 18. & BIG IS GOOD & 1 & 0 & 0 & 1 \\
\hline 19. & BEGINNING IS BIRTH & 1 & 0 & 0 & 1 \\
\hline 20. & UNITY IS SHARING & 1 & 0 & 0 & 1 \\
\hline 21. & EXPRESSING ONE'S OPINION IS PREACHING & 1 & 1 & 0 & 0 \\
\hline 22. & DEATH IS LOSS & 1 & 1 & 0 & 0 \\
\hline 23. & $\begin{array}{l}\text { OPEN BORDERS ARE AN ALTAR FOR RITUAL } \\
\text { SACRIFICE }\end{array}$ & 1 & 1 & 0 & 0 \\
\hline 24. & SERIOUS PROBLEMS ARE SLAUGHTER & 1 & 0 & 0 & 1 \\
\hline 25. & EMOTION IS TEMPERATURE & 1 & 1 & 0 & 0 \\
\hline 26. & KIND IS WARM & 1 & 1 & 0 & 0 \\
\hline 27. & RESTRICTIONS ARE WEIGHT & 1 & 1 & 0 & 0 \\
\hline 28. & A FINANCIAL OBLIGATION IS PRESSURE & 1 & 1 & 0 & 0 \\
\hline 29. & EXPENSES ARE BAGGAGE & 1 & 0 & 0 & 1 \\
\hline 30. & TRUTH IS STRAIGHT & 1 & 1 & 0 & 0 \\
\hline
\end{tabular}




\section{Appendix B}

\section{Metaphors in Trump's Discourse}

\begin{tabular}{|c|c|c|c|}
\hline \# & Text passage & Metaphor & Speech \\
\hline \multicolumn{4}{|c|}{ Person Metaphors } \\
\hline 1. & $\begin{array}{l}\text { a country of generosity and } \\
\text { warmth }\end{array}$ & A NATION IS A PERSON & Acceptance speech \\
\hline 2. & $\begin{array}{l}\text { the crime and violence that today } \\
\text { afflicts our nation }\end{array}$ & A NATION IS A PERSON & Acceptance speech \\
\hline 3. & $\begin{array}{l}\text { Iraq was seeing a big, big } \\
\text { reduction in violence }\end{array}$ & A NATION IS A PERSON & Acceptance speech \\
\hline 4. & $\begin{array}{l}\text { Iran was being choked by } \\
\text { sanctions }\end{array}$ & A NATION IS A PERSON & Acceptance speech \\
\hline 5. & Muslim brotherhood & ALLIES ARE FAMILY RELATIONS & Acceptance speech \\
\hline 6. & $\begin{array}{l}\text { political system lacks the will, or } \\
\text { the courage, or the basic decency }\end{array}$ & A POLITICAL SYSTEM IS A PERSON & Acceptance speech \\
\hline 7. & a nation in mourning & A NATION IS A PERSON & Acceptance speech \\
\hline 8. & $\begin{array}{l}\text { our laws will finally receive the } \\
\text { respect they deserve }\end{array}$ & LAWS ARE PEOPLE & Acceptance speech \\
\hline 9. & $\begin{array}{l}\text { fair trade policy that protects our } \\
\text { jobs and stands up to countries } \\
\text { that cheat }\end{array}$ & A NATION IS A PERSON & Acceptance speech \\
\hline 10. & job killing trade deal & A TRADE DEAL IS A MURDERER & Acceptance speech \\
\hline 11. & horrible and unfair trade deals & $\begin{array}{l}\text { A TRADE DEAL IS AN IMMORAL } \\
\text { PERSON }\end{array}$ & Acceptance speech \\
\hline 12. & $\begin{array}{l}\text { I will make individual deals with } \\
\text { individual countries }\end{array}$ & A NATION IS A PERSON & Acceptance speech \\
\hline 13. & country that cheats & A NATION IS A PERSON & Acceptance speech \\
\hline 14. & China's outrageous theft & A NATION IS A PERSON & Acceptance speech \\
\hline & job-killers & JOBS ARE PEOPLE & Acceptance speech \\
\hline & our depleted military & MILITARY IS A PERSON & Acceptance speech \\
\hline 17. & History is watching us now. & HISTORY IS A PERSON & Acceptance speech \\
\hline 18. & It's waiting to see [about history] & HISTORY IS A PERSON & Acceptance speech \\
\hline 19. & $\begin{array}{l}\text { America is still free and } \\
\text { independent and strong }\end{array}$ & A NATION IS A PERSON & Acceptance speech \\
\hline & $\begin{array}{l}\text { We Will Make America Strong } \\
\text { Again }\end{array}$ & A NATION IS A PERSON & Acceptance speech \\
\hline
\end{tabular}




\begin{tabular}{|c|c|c|c|}
\hline \# & Text passage & Metaphor & Speech \\
\hline \multicolumn{4}{|c|}{ Person Metaphors } \\
\hline 21. & $\begin{array}{l}\text { We Will Make America Proud } \\
\text { Again }\end{array}$ & A NATION IS A PERSON & Acceptance speech \\
\hline 22. & $\begin{array}{l}\text { now it is time for America to bind } \\
\text { the wounds of division }\end{array}$ & A NATION IS A PERSON & Victory speech \\
\hline 23. & $\begin{array}{l}\text { the strongest economy anywhere } \\
\text { in the world }\end{array}$ & ECONOMY IS A PERSON & Victory speech \\
\hline 24. & $\begin{array}{l}\text { we will have great relationships } \\
\text { (with other nations) }\end{array}$ & A NATION IS A PERSON & Victory speech \\
\hline 25. & $\begin{array}{l}\text { we expect to have great, great } \\
\text { relationships }\end{array}$ & A NATION IS A PERSON & Victory speech \\
\hline 26. & $\begin{array}{l}\text { we must reclaim our country's } \\
\text { destiny }\end{array}$ & A NATION IS A PERSON & Victory speech \\
\hline 27. & $\begin{array}{l}\text { we will always put America's } \\
\text { interests first }\end{array}$ & A NATION IS A PERSON & Victory speech \\
\hline 28. & depletion of our military & THE MILITARY IS A PERSON & Inauguration speech \\
\hline 29. & $\begin{array}{l}\text { the crime and gangs and drugs } \\
\text { that have stolen too many lives } \\
\text { and robbed our country of so } \\
\text { much unrealized potential }\end{array}$ & A NATION IS A PERSON & Inauguration speech \\
\hline 30. & $\begin{array}{l}\text { the wealth, strength, and } \\
\text { confidence of our country has } \\
\text { disappeared over the horizon }\end{array}$ & A NATION IS A PERSON & Inauguration speech \\
\hline 31. & $\begin{array}{l}\text { the factories shuttered and left our } \\
\text { shores }\end{array}$ & BUILDINGS ARE PEOPLE & Inauguration speech \\
\hline 32. & $\begin{array}{l}\text { We must protect our borders from } \\
\text { the ravages of other countries }\end{array}$ & OTHER NATIONS ARE THIEVES & Inauguration speech \\
\hline 33. & $\begin{array}{l}\text { (other countries) stealing our } \\
\text { companies and destroying our } \\
\text { jobs }\end{array}$ & OTHER NATIONS ARE THIEVES & Inauguration speech \\
\hline 34. & $\begin{array}{l}\text { we will seek friendship and } \\
\text { goodwill with the nations of the } \\
\text { world }\end{array}$ & A NATION IS A PERSON & Inauguration speech \\
\hline & $\begin{array}{l}\text { the right of all nations to put their } \\
\text { own interests first }\end{array}$ & A NATION IS A PERSON & Inauguration speech \\
\hline 36. & $\begin{array}{l}\text { a nation is only living as long as it } \\
\text { is striving }\end{array}$ & A NATION IS A PERSON & Inauguration speech \\
\hline & the face of the Earth & A PLANET IS A PERSON & Inauguration speech \\
\hline
\end{tabular}




\begin{tabular}{|c|c|c|c|}
\hline$\#$ & Text passage & Metaphor & Speech \\
\hline \multicolumn{4}{|c|}{ Person Metaphors } \\
\hline 38. & $\begin{array}{l}\text { no challenge can match the heart } \\
\text { and fight and spirit of America }\end{array}$ & NATION (AMERICA) IS A PERSON & Inauguration speech \\
\hline 39. & $\begin{array}{l}\text { to free the Earth from the miseries } \\
\text { of disease }\end{array}$ & A PLANET IS A PERSON & Inauguration speech \\
\hline 40. & $\begin{array}{l}\text { a new national pride will stir our } \\
\text { souls, lift our sights, and heal our } \\
\text { divisions }\end{array}$ & PATRIOTISM IS A DOCTOR & Inauguration speech \\
\hline 41. & $\begin{array}{l}\text { we will make America strong } \\
\text { again }\end{array}$ & A NATION IS A PERSON & Inauguration speech \\
\hline 42. & $\begin{array}{l}\text { we will make America wealthy } \\
\text { again }\end{array}$ & A NATION IS A PERSON & Inauguration speech \\
\hline 43. & $\begin{array}{l}\text { we will make America proud } \\
\text { again }\end{array}$ & A NATION IS A PERSON & Inauguration speech \\
\hline 44. & $\begin{array}{l}\text { when you open your heart to } \\
\text { patriotism }\end{array}$ & PATRIOTISM IS A VISITOR & Inauguration speech \\
\hline 45. & $\begin{array}{l}\text { fair trade policy that protects our } \\
\text { jobs and stands up to countries } \\
\text { that cheat }\end{array}$ & A POLICY IS A PERSON & Acceptance speech \\
\hline 46. & $\begin{array}{l}\text { trade deals that strip us of our } \\
\text { jobs, and strip us of our wealth as } \\
\text { a country }\end{array}$ & $\begin{array}{l}\text { A TRADE DEAL IS AN IMMORAL } \\
\text { PERSON }\end{array}$ & Acceptance speech \\
\hline 47. & $\begin{array}{l}\text { trade deals that strip us of our } \\
\text { jobs, and strip us of our wealth as } \\
\text { a country }\end{array}$ & A NATION IS A PERSON & Acceptance speech \\
\hline 48. & $\begin{array}{l}\text { who has used the pulpit of the } \\
\text { presidency }\end{array}$ & A PRESIDENT IS A PREACHER & Acceptance speech \\
\hline
\end{tabular}

\begin{tabular}{llll}
\hline Servant Metaphors & & \\
\hline 49. & $\begin{array}{l}\text { my opponent would rather } \\
\text { protect bureaucrats than serve } \\
\text { American children }\end{array}$ & POLITICIANS ARE SERVANTS & Acceptance speech \\
\hline 50. & those who serve this country & $\begin{array}{l}\text { THE MILITARY PERSONNEL ARE } \\
\text { SERVANTS }\end{array}$ & Acceptance speech \\
\hline 51. & her service to our country & POLITICIANS ARE SERVANTS & Victory speech \\
\hline 52. & nation exists to serve its citizens & A NATION IS A SERVANT & Inauguration speech \\
\hline 53. & who want and expect our & POLITICIANS ARE SERVANTS & Victory speech \\
\hline
\end{tabular}




\begin{tabular}{llll}
\hline Guide Metaphors & & \\
\hline 54. & $\begin{array}{l}\text { protection will lead to great } \\
\text { prosperity and strength }\end{array}$ & $\begin{array}{l}\text { PROTECTION IS A GUIDE TOWARDS } \\
\text { WELL-BEING }\end{array}$ & Inauguration speech \\
\hline 55. & we will follow two simple rules & REGULATIONS ARE GUIDES & Inauguration speech \\
\hline 56. & $\begin{array}{l}\text { to impose our way of life on } \\
\text { anyone, but rather to let it shine as } \\
\text { an example for everyone to follow }\end{array}$ & AMERICA IS A GUIDE & Inauguration speech \\
\hline 57. & $\begin{array}{l}\text { your courage and goodness and } \\
\text { love will forever guide us along } \\
\text { the way }\end{array}$ & MORAL VALUES ARE GUIDES & Inauguration speech \\
\hline
\end{tabular}

\begin{tabular}{llll}
\hline \multicolumn{2}{l}{ Animal Metaphors } & & \\
\hline 58. & $\begin{array}{l}\text { illegal immigrants with criminal } \\
\text { records (ordered deported from } \\
\text { our country) are tonight roaming } \\
\text { free }\end{array}$ & IMMIGRANTS ARE ANIMALS & Acceptance speech \\
\hline 59. & $\begin{array}{l}\text { they are being released (by the } \\
\text { tens of thousands into our } \\
\text { communities) with no regard for } \\
\text { the impact on public safety or } \\
\text { resources }\end{array}$ & IMMIGRANTS ARE ANIMALS & Acceptance speech \\
\hline 60. & stamping out Islamic terrorism & TERRORISTS ARE INSECTS & Acceptance speech \\
\hline 61. & $\begin{array}{l}\text { one such border-crosser was } \\
\text { released }\end{array}$ & IMMIGRANTS ARE ANIMALS & Acceptance speech \\
\hline 62. & they are throwing money at her & $\begin{array}{l}\text { WASTING IS THROWING A PRECIOUS } \\
\text { OBJECT TO AN ANIMAL }\end{array}$ & Acceptance speech \\
\hline 63. & they are throwing money at her & $\begin{array}{l}\text { CLINTON IS A PIG [CASTING PEARLS } \\
\text { BEFORE SWINE] }\end{array}$ & Acceptance speech \\
\hline 64. & brutal Islamic terrorism & TERRORISM IS AN ANIMAL & Acceptance speech \\
\hline 65. & $\begin{array}{l}\text { Americans were savagely } \\
\text { murdered by an Islamic terrorist }\end{array}$ & A TERRORIST IS AN ANIMAL & Acceptance speech \\
\hline
\end{tabular}




\begin{tabular}{llll}
\hline$\# \quad$ Text passage & Metaphor & Speech \\
\hline \hline Animal Metaphors & & \\
\hline 66. & $\begin{array}{l}\text { (On Monday, we heard from three } \\
\text { parents whose children were } \\
\text { killed by illegal immigrants Mary }\end{array}$ & & IMMIGRANTS ARE ANIMALS \\
& $\begin{array}{l}\text { Ann Mendoza, Sabine Durden, } \\
\text { and my friend Jamiel Shaw. They speech } \\
\text { are just three brave representatives } \\
\text { of many thousands who have }\end{array}$ & & \\
& $\begin{array}{l}\text { suffered so gravely). } \\
\text { Americans who have been so } \\
\text { brutally murdered, and who have } \\
\text { suffered so so horribly }\end{array}$ & & \\
\hline 67. & $\begin{array}{l}\text { companies and new jobs to come } \\
\text { roaring back into our country }\end{array}$ & COMPANIES ARE LIONS & Acceptance speech \\
\hline 68. & $\begin{array}{l}\text { I will harness the creative talents } \\
\text { of our people }\end{array}$ & TALENTS ARE DRAFT HORSES & Victory speech \\
\hline 69. & $\begin{array}{l}\text { mothers and children trapped in } \\
\text { poverty }\end{array}$ & PEOPLE ARE ANIMALS & Inauguration speech \\
\hline 70. & $\begin{array}{l}\text { to harness the energies, industries } \\
\text { and technologies of tomorrow }\end{array}$ & ENERGIES, INDUSTRIES, AND \\
\hline
\end{tabular}

\section{Object Metaphors}

\begin{tabular}{llll}
\hline 71. & $\begin{array}{l}\text { (I humbly and gratefully) accept } \\
\text { your nomination }\end{array}$ & A NOMINATION IS AN OBJECT & Acceptance speech \\
\hline 72. & $\begin{array}{l}\text { (the crime and violence that today } \\
\text { afflicts our nation) come to an end }\end{array}$ & $\begin{array}{l}\text { CRIME AND VIOLENCE IS A MOVING } \\
\text { OBJECT }\end{array}$ & Acceptance speech \\
\hline 73. & $\begin{array}{l}\text { the Democrats are holding their } \\
\text { convention next week }\end{array}$ & A CONVENTION IS AN OBJECT & Acceptance speech \\
\hline 74. & he took office & A JOB IS AN OBJECT & Acceptance speech \\
\hline 75. & $\begin{array}{l}\text { (President Obama) took his oath } \\
\text { of office }\end{array}$ & AN OATH IS AN OBJECT & Acceptance speech \\
\hline 76. & $\begin{array}{l}\text { to put Hillary Clinton in charge } \\
\text { of America's foreign policy }\end{array}$ & PEOPLE ARE OBJECTS & Acceptance speech \\
\hline 77. & to retake control & CONTROL IS AN OBJECT & Acceptance speech \\
\hline 78. & $\begin{array}{l}\text { (I will) share with you my plan of } \\
\text { action }\end{array}$ & A PLAN IS AN OBJECT & Acceptance speech \\
\hline 79. & our plan will put America first & A NATION IS AN OBJECT & Acceptance speech \\
\hline 80. & put America first & A NATION IS AN OBJECT & Acceptance speech \\
\hline
\end{tabular}




\begin{tabular}{|c|c|c|c|}
\hline \# & Text passage & Metaphor & Speech \\
\hline \multicolumn{4}{|c|}{ Object Metaphors } \\
\hline 81. & $\begin{array}{l}\text { a Secretary of State illegally stores } \\
\text { her emails }\end{array}$ & E-MAILS ARE OBJECTS & Acceptance speech \\
\hline 82. & $\begin{array}{l}\text { (a Secretary of State) puts our } \\
\text { country at risk }\end{array}$ & A NATION IS AN OBJECT & Acceptance speech \\
\hline 83. & $\begin{array}{l}\text { (the Secretary of State was } \\
\text { "extremely careless" and } \\
\text { "negligent,") in handling our } \\
\text { classified secrets }\end{array}$ & SECRETS ARE OBJECTS & Acceptance speech \\
\hline 84. & $\begin{array}{l}\text { we will bring the same economic } \\
\text { success to America }\end{array}$ & SUCCESS IS AN OBJECT & Acceptance speech \\
\hline 85. & when I take the oath of office & AN OATH IS AN OBJECT & Acceptance speech \\
\hline 86. & $\begin{array}{l}\text { every action I take, I will ask } \\
\text { myself }\end{array}$ & ACTIONS ARE OBJECTS & Acceptance speech \\
\hline 87. & $\begin{array}{l}\text { the failed policy of nation } \\
\text { building and regime change that } \\
\text { Hillary Clinton pushed in Iraq, } \\
\text { Libya, Egypt and Syria }\end{array}$ & POLICY IS AN OBJECT & Acceptance speech \\
\hline 88. & share our goal & GOALS ARE OBJECTS & Acceptance speech \\
\hline 89. & $\begin{array}{l}\text { the United States has been picking } \\
\text { up the cost }\end{array}$ & EXPENDITURE IS AN OBJECT & Acceptance speech \\
\hline 90. & share in their pain & PAIN IS AN OBJECT & Acceptance speech \\
\hline 91. & to send them our love & LOVE IS AN OBJECT & Acceptance speech \\
\hline 92. & $\begin{array}{l}\text { our laws will finally receive the } \\
\text { respect they deserve }\end{array}$ & RESPECT IS AN OBJECT & Acceptance speech \\
\hline 93. & $\begin{array}{l}\text { from the moment I take the oath } \\
\text { of office }\end{array}$ & AN OATH IS AN OBJECT & Acceptance speech \\
\hline 94. & the day I take the oath of office & AN OATH IS AN OBJECT & Acceptance speech \\
\hline 95. & $\begin{array}{l}\text { I am going to bring our jobs back } \\
\text { to Ohio and Pennsylvania and } \\
\text { New York and Michigan and all } \\
\text { of America }\end{array}$ & A JOB IS AN OBJECT & Acceptance speech \\
\hline 96. & intellectual property & IDEAS ARE POSSESSIONS & Acceptance speech \\
\hline 97. & $\begin{array}{l}\text { to put the great miners and steel } \\
\text { workers of our country out of } \\
\text { work }\end{array}$ & PEOPLE ARE OBJECTS & Acceptance speech \\
\hline 98. & $\begin{array}{l}\text { Ten Point Plan has received } \\
\text { tremendous veteran support }\end{array}$ & SUPPORT IS AN OBJECT & Acceptance speech \\
\hline
\end{tabular}




\begin{tabular}{|c|c|c|c|}
\hline \# & Text passage & Metaphor & Speech \\
\hline \multicolumn{4}{|c|}{ Object Metaphors } \\
\hline 99. & the support they have given me & SUPPORT IS AN OBJECT & Acceptance speech \\
\hline 100. & their voice has been taken away & VOICE IS AN OBJECT & Acceptance speech \\
\hline 101. & I will always give you my love & LOVE IS AN OBJECT & Acceptance speech \\
\hline 102. & deliver a victory & VICTORY IS AN OBJECT & Acceptance speech \\
\hline 103. & $\begin{array}{l}\text { I'm reaching out to you for your } \\
\text { guidance and your help }\end{array}$ & GUIDANCE AND HELP IS AN OBJECT & Victory speech \\
\hline 104. & $\begin{array}{l}\text { it is a movement comprised of } \\
\text { Americans from all races, } \\
\text { religions, backgrounds, and beliefs }\end{array}$ & A MOVEMENT IS AN OBJECT & Victory speech \\
\hline 105. & $\begin{array}{l}\text { we will put millions of our people } \\
\text { to work }\end{array}$ & PEOPLE ARE OBJECTS & Victory speech \\
\hline 106. & no dream is too big & A DREAM IS AN OBJECT & Victory speech \\
\hline 107. & no challenge is too great & CHALLENGE IS AN OBJECT & Victory speech \\
\hline 108. & I would like to take this moment & TIME IS AN OBJECT & Victory speech \\
\hline 109. & $\begin{array}{l}\text { I want to give a very special } \\
\text { thanks }\end{array}$ & GRATITUDE IS AN OBJECT & Victory speech \\
\hline 110. & transfer of power & POLITICAL POWER IS AN OBJECT & Victory speech \\
\hline 111. & $\begin{array}{l}\text { transferring power from one } \\
\text { administration to another }\end{array}$ & POLITICAL POWER IS AN OBJECT & Victory speech \\
\hline 112. & $\begin{array}{l}\text { we are transferring power from } \\
\text { Washington, D.C. }\end{array}$ & POLITICAL POWER IS AN OBJECT & Victory speech \\
\hline 113. & giving it [power] back to you & POLITICAL POWER IS AN OBJECT & Victory speech \\
\hline 114. & $\begin{array}{l}\text { this moment is your moment: it } \\
\text { belongs to you }\end{array}$ & TIME IS AN OBJECT & Victory speech \\
\hline 115. & $\begin{array}{l}\text { the crime and gangs and drugs } \\
\text { that have stolen too many lives } \\
\text { and robbed our country of so } \\
\text { much unrealized potential }\end{array}$ & LIFE IS A VALUABLE POSSESSION & Victory speech \\
\hline 116. & $\begin{array}{l}\text { we share one heart, one home, } \\
\text { and one glorious destiny }\end{array}$ & DESTINY IS AN OBJECT & Victory speech \\
\hline 117. & the oath of office I take today & AN OATH IS AN OBJECT & Victory speech \\
\hline 118. & we will bring back our jobs & A JOB IS AN OBJECT & Victory speech \\
\hline 119. & we will bring back our wealth & WEALTH IS AN OBJECT & Victory speech \\
\hline 120. & we will bring back our dreams & A DREAM IS AN OBJECT & Victory speech \\
\hline 121. & $\begin{array}{l}\text { we will get our people off of } \\
\text { welfare and back to work }\end{array}$ & PEOPLE ARE OBJECTS & Victory speech \\
\hline 122. & room for prejudice & PREJUDICE IS AN OBJECT & Victory speech \\
\hline
\end{tabular}




\begin{tabular}{|c|c|c|c|}
\hline \# & Text passage & Metaphor & Speech \\
\hline \multicolumn{4}{|c|}{ Object Metaphors } \\
\hline 123. & $\begin{array}{l}\text { major donors are lining up behind } \\
\text { the campaign of my opponent }\end{array}$ & $\begin{array}{l}\text { AN ELECTION CAMPAIGN IS AN } \\
\text { OBJECT }\end{array}$ & Acceptance speech \\
\hline 124. & $\begin{array}{l}\text { to leverage their tremendous } \\
\text { talent }\end{array}$ & A TALENT IS AN OBJECT & Victory speech \\
\hline 125. & $\begin{array}{l}\text { mothers and children trapped in } \\
\text { poverty }\end{array}$ & POVERTY IS A TRAP & Inauguration speech \\
\hline 126. & pursue solidarity & $\begin{array}{l}\text { SOLIDARITY IS AN OBJECT TO BE } \\
\text { PURSUED }\end{array}$ & Inauguration speech \\
\hline 127. & $\begin{array}{l}\text { we must break free from the petty } \\
\text { politics of the past }\end{array}$ & BAD POLITICS IS CHAINS & Acceptance speech \\
\hline 128. & $\begin{array}{l}\text { we, the citizens of America, are } \\
\text { now joined in a great national } \\
\text { effort }\end{array}$ & PEOPLE ARE LINKS OF A CHAIN & Inauguration speech \\
\hline 129. & $\begin{array}{l}\text { (her bad instincts and her bad } \\
\text { judgment) are what caused so } \\
\text { many of the disasters unfolding } \\
\text { today }\end{array}$ & PROBLEMS ARE FABRIC & Acceptance speech \\
\hline 130. & families ripped apart & FAMILIES ARE FABRIC & Acceptance speech \\
\hline 131. & $\begin{array}{l}\text { the wealth of our middle class has } \\
\text { been ripped from their homes }\end{array}$ & WEALTH IS A FABRIC & Victory speech \\
\hline 132. & $\begin{array}{l}\text { we cannot afford to be so } \\
\text { politically correct anymore }\end{array}$ & $\begin{array}{l}\text { POLITICAL CORRECTNESS IS AN } \\
\text { EXPENSIVE ITEM }\end{array}$ & Acceptance speech \\
\hline 133. & the carefully-crafted lies & $\begin{array}{l}\text { LIES ARE SKILFULLY MANUFACTURED } \\
\text { GOODS }\end{array}$ & Acceptance speech \\
\hline 134. & to produce a change in outcomes & RESULTS ARE PRODUCTS & Acceptance speech \\
\hline 135. & $\begin{array}{l}\text { decades of record immigration } \\
\text { have produced lower wages and } \\
\text { higher unemployment }\end{array}$ & $\begin{array}{l}\text { WAGES AND UNEMPLOYMENT ARE } \\
\text { PRODUCTS }\end{array}$ & Acceptance speech \\
\hline
\end{tabular}

\section{Physical Suffering Metaphors}

\begin{tabular}{llll}
\hline 136. & $\begin{array}{l}\text { the crime and violence that today } \\
\text { afflicts our nation }\end{array}$ & CRIME AND VIOLENCE IS A DISEASE & Acceptance speech \\
\hline 137. & wounded American families & $\begin{array}{l}\text { EMOTIONAL SUFFERING IS A } \\
\text { PHYSICAL wOUND }\end{array}$ & Acceptance speech \\
\hline 138. & $\begin{array}{l}\text { relief from uncontrolled } \\
\text { immigration }\end{array}$ & IMMIGRATION IS PAIN & Acceptance speech \\
\hline 139. & agreement that hurts our workers & BAD AGREEMENTS ARE PAIN & Acceptance speech \\
\hline
\end{tabular}




\begin{tabular}{llll}
\hline$\#$ & Text passage & Metaphor & Speech \\
\hline \hline Physical Suffering Metaphors & & \\
\hline 140. & $\begin{array}{l}\text { (middle-income Americans and } \\
\text { businesses) will experience } \\
\text { profound relief }\end{array}$ & TAXES ARE PAIN & Acceptance speech \\
\hline 141. & $\begin{array}{l}\text { now it is time for America to bind } \\
\text { the wounds of division }\end{array}$ & SOCIAL DIVISION IS A WOUND & Victory speech \\
\hline 142. & their pain is our pain & PROBLEMS ARE PHYSICAL SUFFERING & Inauguration speech \\
\hline 143. & $\begin{array}{l}\text { subsidized the armies of other } \\
\text { countries while allowing for the } \\
\text { very sad depletion of our military }\end{array}$ & FINANCIAL LOSS IS BLEEDING & Inauguration speech \\
\hline 144. & $\begin{array}{l}\text { a new national pride will stir our } \\
\text { souls, lift our sights, and heal our } \\
\text { divisions }\end{array}$ & SOCIAL DIVISION IS A WOUND & Inauguration speech \\
\hline
\end{tabular}

\section{Force Metaphors}

\begin{tabular}{llll}
\hline 145. & $\begin{array}{l}\text { they are being released (by the } \\
\text { tens of thousands into our } \\
\text { communities) with no regard for } \\
\text { the impact on public safety or } \\
\text { resources }\end{array}$ & $\begin{array}{l}\text { IMMIGRANTS ARE A DESTRUCTIVE } \\
\text { FORCE }\end{array}$ & Acceptance speech \\
\hline 146. & the problems we face now & RESISTANCE IS REMAINING UPRIGHT & Acceptance speech \\
\hline 147. & $\begin{array}{l}\text { (a Secretary of State) faces no } \\
\text { consequence }\end{array}$ & DIFFICULTIES ARE OPPOSING FORCES & Acceptance speech \\
\hline 148. & $\begin{array}{l}\text { the powerful can no longer beat } \\
\text { up on people }\end{array}$ & AUTHORITY IS PHYSICAL POWER & Acceptance speech \\
\hline 149. & $\begin{array}{l}\text { the growing threats we face from } \\
\text { outside the country }\end{array}$ & DIFFICULTIES ARE OPPOSING FORCES & Acceptance speech \\
\hline 150. & $\begin{array}{l}\text { fair trade policy that protects our } \\
\text { jobs and stands up to countries } \\
\text { that cheat }\end{array}$ & RESISTANCE IS REMAINING UPRIGHT & Acceptance speech \\
\hline 151. & $\begin{array}{l}\text { devastating currency } \\
\text { manipulation }\end{array}$ & $\begin{array}{l}\text { CURRENCY MANIPULATION IS A } \\
\text { DEVASTATING FORCE }\end{array}$ & Acceptance speech \\
\hline 152. & we will face challenges & DIFFICULTIES ARE OPPOSING FORCES & Inauguration speech \\
\hline 153. & we will confront hardships & DIFFICULTIES ARE OPPOSING FORCES & Inauguration speech \\
\hline 154. & $\begin{array}{l}\text { a new national pride will stir our } \\
\text { souls, lift our sights, and heal our } \\
\text { divisions }\end{array}$ & PATRIOTISM IS A FORCE & Inauguration speech \\
\hline 155. & domestic disaster & A PROBLEM IS A DESTRUCTIVE FORCE & Acceptance speech \\
\hline
\end{tabular}




\begin{tabular}{|c|c|c|c|}
\hline \# & Text passage & Metaphor & Speech \\
\hline \multicolumn{4}{|c|}{ Force Metaphors } \\
\hline 156. & $\begin{array}{l}\text { (her bad instincts and her bad } \\
\text { judgment) are what caused so } \\
\text { many of the disasters unfolding } \\
\text { today }\end{array}$ & A MISTAKE IS A DESTRUCTIVE FORCE & Acceptance speech \\
\hline 157. & disastrous trade deals & $\begin{array}{l}\text { A TRADE DEAL IS A DESTRUCTIVE } \\
\text { FORCE }\end{array}$ & Acceptance speech \\
\hline 158. & colossal mistakes and disasters & A MISTAKE IS A DESTRUCTIVE FORCE & Acceptance speech \\
\hline 159. & $\begin{array}{l}\text { we will repeal and replace } \\
\text { disastrous Obamacare }\end{array}$ & $\begin{array}{l}\text { OBAMACARE IS A DESTRUCTIVE } \\
\text { FORCE }\end{array}$ & Acceptance speech \\
\hline 160. & $\begin{array}{l}\text { and we will fix TSA at the } \\
\text { airports which is a total disaster }\end{array}$ & $\begin{array}{l}\text { TRANSPORTATION SECURITY } \\
\text { ADMINISTRATION IS A } \\
\text { DESTRUCTIVE FORCE }\end{array}$ & Acceptance speech \\
\hline
\end{tabular}

\section{Building Metaphors}

\begin{tabular}{llll}
\hline 161. & safety will be restored & SAFETY IS A BUILDING & Acceptance speech \\
\hline 162. & bringing down crime & CRIME IS A BUILDING & Acceptance speech \\
\hline 163. & the world is far less stable & THE WORLD IS A BUILDING & Acceptance speech \\
\hline 164. & the world is far less stable & PEACE IS STABILITY & Acceptance speech \\
\hline 165. & Libya was stable & $\begin{array}{l}\text { A NATION IS A BUILDING } \\
\text { PEACE IS STABILITY }\end{array}$ & Acceptance speech \\
\hline 166. & $\begin{array}{l}\text { communities crushed by our } \\
\text { horrible and unfair trade deals }\end{array}$ & COMMUNITIES ARE BUILDINGS & Acceptance speech \\
\hline 167. & rebuild America & A NATION IS A BUILDING & Acceptance speech \\
\hline 168. & $\begin{array}{l}\text { I will restore law and order to our } \\
\text { country }\end{array}$ & LAW AND ORDER IS A BUILDING & Acceptance speech \\
\hline 169. & lives ruined & LIFE IS A BUILDING & Acceptance speech \\
\hline 170. & destroying ISIS & ISIS IS A BUILDING & Acceptance speech \\
\hline 171. & Peace will be restored & PEACE IS A BUILDING & Acceptance speech \\
\hline 172. & destroying our middle class & SOCIAL CLASS IS A BUILDING & Acceptance speech \\
\hline 173. & no longer will we enter into these & TRANSACTION IS A BUILDING & Acceptance speech \\
& $\begin{array}{l}\text { massive transactions, with many } \\
\text { countries }\end{array}$ & & \\
\hline 174. & $\begin{array}{l}\text { (we will completely) rebuild our } \\
\text { depleted military }\end{array}$ & THE MILITARY IS A BUILDING & Acceptance speech \\
\hline 175. & rebuilding our nation & A NATION IS A BUILDING & Victory speech \\
\hline 176. & our work on this movement & A MOVEMENT IS A BUILDING & Victory speech \\
\hline
\end{tabular}




\begin{tabular}{|c|c|c|c|}
\hline \# & Text passage & Metaphor & Speech \\
\hline \multicolumn{4}{|c|}{ Building Metaphors } \\
\hline 177. & $\begin{array}{l}\text { rebuilding our country with } \\
\text { American hands and American } \\
\text { labor }\end{array}$ & A NATION IS A BUILDING & Inauguration speech \\
\hline 178. & rusted-out factories & DESOLATION IS A RUSTED BUILDING & Inauguration speech \\
\hline 179. & $\begin{array}{l}\text { to rebuild our country and to } \\
\text { restore its promise }\end{array}$ & $\begin{array}{l}\text { A NATION IS A BUILDING / A } \\
\text { PROMISE IS A BUILDING }\end{array}$ & Inauguration speech \\
\hline 180. & At the bedrock of our politics & POLITICS IS A BUILDING & Inauguration speech \\
\hline 181. & $\begin{array}{l}\text { when you open your heart to } \\
\text { patriotism }\end{array}$ & HEART IS A HOME & Inauguration speech \\
\hline 182. & $\begin{array}{l}\text { (one more child to sacrifice) on } \\
\text { the order and on the altar of open } \\
\text { borders }\end{array}$ & $\begin{array}{l}\text { BORDERS ARE DOORS TO A } \\
\text { BUILDING }\end{array}$ & Acceptance speech \\
\hline
\end{tabular}

\section{Container Metaphors}

\begin{tabular}{llll}
\hline 183. & children are living in poverty & POVERTY IS A CONTAINER & Acceptance speech \\
\hline 184. & $\begin{array}{l}\text { existing massive refugee flows } \\
\text { coming into our country }\end{array}$ & A COUNTRY IS A CONTAINER & Acceptance speech \\
\hline $\begin{array}{l}\text { 185. } \\
\text { to stop the drugs from pouring } \\
\text { into our communities }\end{array}$ & COMMUNITIES ARE CONTAINERS & Acceptance speech \\
\hline 186. & $\begin{array}{l}\text { trillions of dollars will start } \\
\text { flowing into our country }\end{array}$ & A COUNTRY IS A CONTAINER & Acceptance speech \\
\hline 187. & the time for empty talk is over & MEANING IS SUBSTANCE IN A & Inauguration speech \\
\hline 188. & to unlock the mysteries of space & $\begin{array}{l}\text { THE UNKNOWN IS THE CONTENTS } \\
\text { OF A LOCKED CHEST }\end{array}$ & Inauguration speech \\
\hline 189. & $\begin{array}{l}\text { they fill their heart with the same } \\
\text { dreams }\end{array}$ & THE HEART IS A CONTAINER & Inauguration speech \\
\hline 190. & $\begin{array}{l}\text { they are infused with the breath of } \\
\text { life }\end{array}$ & PEOPLE ARE CONTAINERS & Inauguration speech \\
\hline
\end{tabular}

\section{Machine Metaphors}

\begin{tabular}{llll}
\hline 191. & we're going to fix that & $\begin{array}{l}\text { SOLVING PROBLEMS IS FIXING A } \\
\text { MACHINE }\end{array}$ & Acceptance speech \\
\hline 192. & I alone can fix it & $\begin{array}{l}\text { SOLVING PROBLEMS IS FIXING A } \\
\text { MACHINE }\end{array}$ & Acceptance speech \\
\hline
\end{tabular}




\begin{tabular}{llll}
\hline$\#$ & Text passage & Metaphor & Speech \\
\hline \hline Machine Metaphors & & \\
\hline 193. & we will fix his biggest single issue & $\begin{array}{l}\text { SOLVING PROBLEMS IS FIXING A } \\
\text { MACHINE }\end{array}$ & Acceptance speech \\
\hline 194. & $\begin{array}{l}\text { to fix the system so it works justly } \\
\text { for each and every American }\end{array}$ & $\begin{array}{l}\text { THE POLITICAL SYSTEM IS A } \\
\text { MACHINE }\end{array}$ & Acceptance speech \\
\hline 195. & we can fix this problem so quickly & SOLVING PROBLEMS IS FIXING A & Acceptance speech \\
& & MACHINE & Acceptance speech \\
\hline 196. & we will fix TSA at the airports & $\begin{array}{l}\text { TRANSPORTATION SECURITY } \\
\text { ADMINISTRATION IS A MACHINE }\end{array}$ & Acceptance speech \\
\hline 197. & to fix our inner cities & SOLVING PROBLEMS IS FIXING A & Acceptance speech \\
\hline 198. & $\begin{array}{l}\text { to fix the system so it works justly } \\
\text { for each and every American }\end{array}$ & POLITICAL SYSTEM IS A MACHINE & Acceptance speech \\
\hline 199. & $\begin{array}{l}\text { decades of record immigration } \\
\text { have produced lower wages and } \\
\text { higher unemployment }\end{array}$ & IMMIGRATION IS A MACHINE & \\
\hline
\end{tabular}

\begin{tabular}{|c|c|c|c|}
\hline \multicolumn{4}{|c|}{ Journey Metaphors } \\
\hline 200. & way of life & LIFE IS A JOURNEY & Acceptance speech \\
\hline 201. & $\begin{array}{l}\text { he ended the life of an innocent } \\
\text { young girl }\end{array}$ & LIFE IS A JOURNEY & Acceptance speech \\
\hline 202. & $\begin{array}{l}\text { the cycle of human smuggling and } \\
\text { violence }\end{array}$ & $\begin{array}{l}\text { HUMAN SMUGGLING AND VIOLENCE } \\
\text { IS A (NEVER-ENDING) JOURNEY }\end{array}$ & Acceptance speech \\
\hline 203. & $\begin{array}{l}\text { to escape the tremendous cycle of } \\
\text { poverty that they're going } \\
\text { through }\end{array}$ & $\begin{array}{l}\text { POVERTY IS A (NEVER-ENDING) } \\
\text { JOURNEY }\end{array}$ & Acceptance speech \\
\hline 204. & $\begin{array}{l}\text { young people just starting out } \\
\text { their adult lives }\end{array}$ & LIFE IS A JOURNEY & Acceptance speech \\
\hline 205. & in this journey & $\begin{array}{l}\text { AN ELECTION CAMPAIGN IS A } \\
\text { JOURNEY }\end{array}$ & Acceptance speech \\
\hline 206. & this 18 -month journey & $\begin{array}{l}\text { AN ELECTION CAMPAIGN IS A } \\
\text { JOURNEY }\end{array}$ & Victory speech \\
\hline
\end{tabular}

\section{Motion Metaphors}

207. the crime and violence that today

TIME IS MOTION

Acceptance speech afflicts our nation come to an end 


\begin{tabular}{|c|c|c|c|}
\hline \# & Text passage & Metaphor & Speech \\
\hline \multicolumn{4}{|c|}{ Motion Metaphors } \\
\hline \multirow[t]{2}{*}{208.} & the corporate spin & A CHARACTERISTIC IS A PARTICULAR & Acceptance speech \\
\hline & & ROTATION & \\
\hline 209. & rollback of criminal enforcement & CHANGE IS MOTION & Acceptance speech \\
\hline 210. & it will go down in history & TIME IS MOTION & Acceptance speech \\
\hline \multirow[t]{3}{*}{211.} & on the path to nuclear weapons & REACHING A GOAL IS MOTION & Acceptance speech \\
\hline & & ALONG A PATH TOWARDS A & \\
\hline & & DESTINATION & \\
\hline 212. & $\begin{array}{l}\text { she will keep our rigged system in } \\
\text { place }\end{array}$ & CHANGE IS MOTION & Acceptance speech \\
\hline 213. & the time for action has come & TIME IS A MOVING VEHICLE & Acceptance speech \\
\hline 214. & a true step in the right direction & CHANGE IS MOTION & Acceptance speech \\
\hline 215. & $\begin{array}{l}\text { we'll walk away (if we don't get } \\
\text { the deal that we want) }\end{array}$ & REFUSING IS GOING AWAY & Acceptance speech \\
\hline 216. & $\begin{array}{l}\text { ours was not a campaign but } \\
\text { rather an incredible and great } \\
\text { movement }\end{array}$ & CHANGE IS MOTION & Victory speech \\
\hline 217. & $\begin{array}{l}\text { America's infrastructure has fallen } \\
\text { into disrepair and decay }\end{array}$ & DAMAGE IS FALLING & Inauguration speech \\
\hline 218. & $\begin{array}{l}\text { You came by the tens of millions } \\
\text { to become part of a historic } \\
\text { movement }\end{array}$ & CHANGE IS MOTION & Inauguration speech \\
\hline 219. & at the center of this movement & CHANGE IS MOTION & Inauguration speech \\
\hline 220. & now arrives the hour of action & TIME IS MOTION & Inauguration speech \\
\hline 221. & $\begin{array}{l}\text { but his supporters will join our } \\
\text { movement }\end{array}$ & CHANGE IS MOTION & Acceptance speech \\
\hline 222. & $\begin{array}{l}\text { Democrats will join our } \\
\text { movement }\end{array}$ & CHANGE IS MOTION & Acceptance speech \\
\hline 223. & $\begin{array}{l}\text { (you came by the tens of millions) } \\
\text { to become part of a historic } \\
\text { movement }\end{array}$ & CHANGE IS MOTION & Inauguration speech \\
\hline 224. & at the center of this movement & CHANGE IS MOTION & Inauguration speech \\
\hline
\end{tabular}

\begin{tabular}{llll}
\hline \multicolumn{2}{l}{ Spatial Metaphors } & \\
\hline 225. & killings have risen by 50 percent & MORE IS UP & Acceptance speech \\
\hline 226. & they are up nearly 60 percent & MORE IS UP & Acceptance speech \\
\hline
\end{tabular}




\begin{tabular}{|c|c|c|c|}
\hline \# & Text passage & Metaphor & Speech \\
\hline \multicolumn{4}{|c|}{ Spatial Metaphors } \\
\hline 227. & $\begin{array}{l}\text { the number of police officers } \\
\text { killed in the line of duty has risen } \\
\text { by almost } 50 \text { percent }\end{array}$ & MORE IS UP & Acceptance speech \\
\hline 228. & $\begin{array}{l}\text { we will lead our country back to } \\
\text { safety, prosperity, and peace }\end{array}$ & $\begin{array}{l}\text { SAFETY AND PROSPERITY AND } \\
\text { PEACE ARE LOCATIONS }\end{array}$ & Acceptance speech \\
\hline 229. & the line of duty & $\begin{array}{l}\text { DUTY IS AN ORDERLY SPATIAL } \\
\text { ARRANGEMENT }\end{array}$ & Acceptance speech \\
\hline 230. & household incomes are down & LESS IS DOWN & Acceptance speech \\
\hline 231. & $\begin{array}{l}\text { our sailors being forced to their } \\
\text { knees }\end{array}$ & HUMILIATION IS DOWN & Acceptance speech \\
\hline 232. & $\begin{array}{l}\text { major donors are lining up behind } \\
\text { the campaign of my opponent }\end{array}$ & SUPPORT IS PROXIMITY & Acceptance speech \\
\hline 233. & $\begin{array}{l}\text { to have at my side the next Vice } \\
\text { President of the United States }\end{array}$ & SUPPORT IS PROXIMITY & Acceptance speech \\
\hline 234. & $\begin{array}{l}\text { tonight, this candidate and the } \\
\text { whole nation stand in their corner } \\
\text { to support them }\end{array}$ & SUPPORT IS PROXIMITY & Acceptance speech \\
\hline 235. & $\begin{array}{l}\text { nothing has affected me more } \\
\text { deeply }\end{array}$ & EMOTIONAL INTENSITY IS DEPTH & Acceptance speech \\
\hline 236. & to listen very very closely & ATTENTION IS PROXIMITY & Acceptance speech \\
\hline 237. & $\begin{array}{l}\text { we will rescue kids from failing } \\
\text { schools }\end{array}$ & $\begin{array}{l}\text { BAD SCHOOLS ARE A DANGEROUS } \\
\text { LOCATION }\end{array}$ & Acceptance speech \\
\hline 238. & to have at my side my wife & SUPPORT IS PROXIMITY & Acceptance speech \\
\hline 239. & if we will rise to the occasion & STRONG IS UP & Acceptance speech \\
\hline 240. & $\begin{array}{l}\text { to leverage their tremendous } \\
\text { talent }\end{array}$ & SUPPORTING IS LIFTING UP & Victory speech \\
\hline 241. & $\begin{array}{l}\text { we will get along with all other } \\
\text { nations willing to get along with } \\
\text { us }\end{array}$ & SYMPATHY IS PROXIMITY & Victory speech \\
\hline 242. & $\begin{array}{l}\text { America will no longer settle for } \\
\text { anything less than the best }\end{array}$ & $\begin{array}{l}\text { AGREEING IS SETTLING AT A } \\
\text { LOCATION }\end{array}$ & Victory speech \\
\hline 243. & we will seek common ground & AGREEMENT IS PROXIMITY & Victory speech \\
\hline 244. & $\begin{array}{l}\text { I want to thank my parents, who I } \\
\text { know are looking down on me } \\
\text { right now }\end{array}$ & HEAVEN IS UP & Victory speech \\
\hline 245. & $\begin{array}{l}\text { he is highly respected in } \\
\text { Washington }\end{array}$ & HONOR IS UP & Victory speech \\
\hline
\end{tabular}




\begin{tabular}{llll}
\hline$\#$ & Text passage & Metaphor & Speech \\
\hline \hline Spatial Metaphors & & \\
\hline 246. & that I will not let you down & DISAPPOINTMENT IS DOwN & Victory speech \\
\hline 247. & $\begin{array}{l}\text { I look very much forward to } \\
\text { being your president }\end{array}$ & FUTURE IS AHEAD & Victory speech \\
\hline 248. & $\begin{array}{l}\text { at the end of two years or three } \\
\text { years or four years or maybe even } \\
\text { eight years }\end{array}$ & TIME IS SPACE & Victory speech \\
\hline 249. & $\begin{array}{l}\text { we will rediscover our loyalty to } \\
\text { each other }\end{array}$ & LOYALTY IS A LOCATION & Victory speech \\
\hline 250. & at the center of this movement & IMPORTANT IS CENTRAL & Inauguration speech \\
\hline 251. & we are looking only to the future & FUTURE IS AHEAD & Inauguration speech \\
\hline 252. & I will never, ever let you down & DISAPPOINTMENT IS DOWN & Inauguration speech \\
\hline 253. & $\begin{array}{l}\text { A new national pride will stir our } \\
\text { souls, lift our sights, and heal our }\end{array}$ & GOOD IS UP & Inauguration speech \\
& divisions & & \\
\hline 254. & product dumping & REDUCING THE PRICE OF A & Acceptance speech \\
& & PRODUCT IS DECREASING VERTICAL & \\
\hline 255. & we will double our growth & INCREASE IN QUANTITY IS INCREASE & Victory speech \\
& & IN SIZE & \\
\hline
\end{tabular}

\begin{tabular}{llll}
\hline Plant & Metaphors & & \\
\hline 256. & $\begin{array}{l}\text { Secretary of State rakes in millions } \\
\text { and millions of dollars }\end{array}$ & $\begin{array}{l}\text { A LOT OF MONEY IS AN ABUNDANCE } \\
\text { OF LEAVES }\end{array}$ & Acceptance speech \\
\hline 257. & $\begin{array}{l}\text { men, women and children } \\
\text { viciously mowed down }\end{array}$ & KILING IS CUTTING DOWN GRASS & Acceptance speech \\
\hline 258. & $\begin{array}{l}\text { we will embark upon a project of } \\
\text { national growth and renewal }\end{array}$ & A NATION IS A PLANT & Victory speech \\
\hline 259. & we will double our growth & ECONOMY IS A PLANT & Victory speech \\
\hline 260. & $\begin{array}{l}\text { a small group in our nation's } \\
\text { Capital has reaped the rewards of } \\
\text { government }\end{array}$ & MONEY ARE CROPS & Inauguration speech \\
\hline 261. & Washington flourished & A CITY IS A PLANT & Inauguration speech \\
\hline 262. & $\begin{array}{l}\text { radical Islamic terrorism, which } \\
\text { we will eradicate completely }\end{array}$ & TERRORISM IS A WEED & Inauguration speech \\
\hline 263. & $\begin{array}{l}\text { our country will thrive and } \\
\text { prosper again }\end{array}$ & A NATION IS A PLANT & Inauguration speech \\
\hline 264. & the urban sprawl of Detroit & A CITY IS A PLANT & Inauguration speech \\
\hline
\end{tabular}




\begin{tabular}{llll}
\hline Money Metaphors & & \\
\hline 265. & $\begin{array}{l}\text { especially when others who have } \\
\text { done far less, have paid so dearly }\end{array}$ & $\begin{array}{l}\text { PUNISHMENT IS PAYING EXCESSIVE } \\
\text { AMOUNTS OF MONEY }\end{array}$ & Acceptance speech \\
\hline 266. & $\begin{array}{l}\text { time I have spent with the } \\
\text { mothers and fathers }\end{array}$ & TIME IS MONEY & Acceptance speech \\
\hline 267. & $\begin{array}{l}\text { we owe her a major debt of } \\
\text { gratitude }\end{array}$ & GRATITUDE IS MONEY & Victory speech \\
\hline 268. & spent my entire life in business & TIME IS MONEY & Victory speech \\
\hline 269. & the time I've spent with them & TIME IS MONEY & Victory speech \\
\hline 270. & we will deal fairly with everyone & PERSONAL RELATIONS ARE BUSINESS & Victory speech \\
\hline
\end{tabular}

\begin{tabular}{llll}
\hline Liquid Metaphors & & \\
\hline 271. & Syria is engulfed in a civil war & WAR IS A FLOOD & Acceptance speech \\
\hline 272. & $\begin{array}{l}\text { existing massive refugee flows } \\
\text { coming into our country }\end{array}$ & IMMIGRATION IS A FLOOD & Acceptance speech \\
\hline 273. & violence spilling across our border & $\begin{array}{l}\text { VIOLENCE IS AN OVERFLOwING } \\
\text { LIQUID }\end{array}$ & Acceptance speech \\
\hline 274. & $\begin{array}{l}\text { to stop the drugs from pouring } \\
\text { into our communities }\end{array}$ & $\begin{array}{l}\text { DRUGS ARE AN UNCONTAINED FLOw } \\
\text { OF WATER }\end{array}$ & Acceptance speech \\
\hline 275. & $\begin{array}{l}\text { trillions of dollars will start } \\
\text { flowing into our country }\end{array}$ & MONEY IS FLOWING WATER & Acceptance speech \\
\hline 276. & $\begin{array}{l}\text { students who are drowning in } \\
\text { debt }\end{array}$ & DEBTS ARE A DEADLY FLOOD & Acceptance speech \\
\hline 277. & $\begin{array}{l}\text { my opponent dismissed the VA } \\
\text { scandal as being not widespread }\end{array}$ & A SCANDAL IS A SUBSTANCE & Acceptance speech \\
\hline 278. & flush with cash & MONEY IS WATER & Inauguration speech \\
\hline 279. & the time for empty talk is over & MEANING IS SUBSTANCE IN A & Inauguration speech \\
\hline 280. & $\begin{array}{l}\text { a new national pride will stir our } \\
\text { souls, lift our sights, and heal our } \\
\text { divisions }\end{array}$ & SOUL IS A LIQUID & Inauguration speech \\
\hline 281. & the untapped potential & POTENTIAL IS A LIQUID & Victory speech \\
\hline 282. & source of pride and joy & PRIDE AND JOY ARE LIQUIDS & Victory speech \\
\hline
\end{tabular}

\section{Competition Metaphors}

\begin{tabular}{llll}
\hline 283. & let's defeat her in November & ELECTIONS ARE A wAR & Acceptance speech \\
\hline 284. & in this race for the White House & ELECTIONS ARE A COMPETITION & Acceptance speech \\
\hline
\end{tabular}




\begin{tabular}{llll}
\hline$\#$ & Text passage & Metaphor & Speech \\
\hline \hline Competition Metaphors & & \\
\hline 285. & struggling citizens & $\begin{array}{l}\text { DEALING WITH PROBLEMS Is } \\
\text { FIGHTING }\end{array}$ & Acceptance speech \\
\hline 286. & presidential race & ELECTIONS ARE A COMPETITION & Acceptance speech \\
\hline 287. & $\begin{array}{l}\text { we don't win anymore, but we are } \\
\text { going to start winning }\end{array}$ & POLITICS IS A COMPETITION & Acceptance speech \\
\hline 288. & we love defeating those people & ELECTIONS ARE A WAR & Acceptance speech \\
\hline 289. & $\begin{array}{l}\text { I can be your champion in the } \\
\text { White House }\end{array}$ & POLITICS IS A COMPETITION & Acceptance speech \\
\hline 290. & $\begin{array}{l}\text { I will fight for you, and I will win } \\
\text { for you }\end{array}$ & TRUMP IS A WARRIOR & Acceptance speech \\
\hline 291. & hard-fought campaign & ELECTIONS ARE FIGHTS & Victory speech \\
\hline 292. & she fought very hard & ELECTIONS ARE FIGHTS & Victory speech \\
\hline 293. & $\begin{array}{l}\text { and while they celebrated in our } \\
\text { nation's capital, there was little to } \\
\text { celebrate for struggling families all } \\
\text { across our land }\end{array}$ & $\begin{array}{l}\text { DEALING WITH POVERTY IS } \\
\text { FIGHTING }\end{array}$ & Inauguration speech \\
\hline 294. & $\begin{array}{l}\text { I will fight for you with every } \\
\text { breath in my body }\end{array}$ & TRUMP IS A WARRIOR & Inauguration speech \\
\hline 295. & very historic victory & ELECTIONS ARE A COMPETITION & Victory speech \\
\hline 296. & unless we win it & $\begin{array}{l}\text { ELECTIONS ARE A COMPETITION } \\
\text { track at Belmont }\end{array}$ & Victory speech \\
\hline 297. & AN ELECTION CAMPAIGN IS A & Victory speech \\
\hline
\end{tabular}

\begin{tabular}{llll}
\hline Seeing Metaphors & & \\
\hline 298. & look the other way & $\begin{array}{l}\text { IGNORING A PROBLEM IS } \\
\text { INTENTIONALLY NOT SEEING }\end{array}$ & Acceptance speech \\
\hline 299. & $\begin{array}{l}\text { (a Secretary of State) faces no } \\
\text { consequence }\end{array}$ & $\begin{array}{l}\text { BEING CONFRONTED wITH STHG. Is } \\
\text { LOOKING AT STHG. }\end{array}$ & Acceptance speech \\
\hline 300. & $\begin{array}{l}\text { facing justice for her terrible } \\
\text { terrible crimes }\end{array}$ & $\begin{array}{l}\text { BEING CONFRONTED WITH STHG. Is } \\
\text { LOOKING AT STHG. }\end{array}$ & Acceptance speech \\
\hline 301. & $\begin{array}{l}\text { the growing threats we face from } \\
\text { outside the country }\end{array}$ & $\begin{array}{l}\text { BEING CONFRONTED WITH sTHG. Is } \\
\text { LOOKING AT STHG. }\end{array}$ & Acceptance speech \\
\hline 302. & I have a different vision & HAVING A PLAN IS SEEING & Acceptance speech \\
\hline 303. & a person of similar views & BELIEVING IS SEEING & Acceptance speech \\
\hline 304. & political views & BELIEVING IS SEEING & Acceptance speech \\
\hline
\end{tabular}




\begin{tabular}{lll}
\hline$\# \quad$ Text passage & Metaphor & Speech \\
\hline \hline Seeing Metaphors & & \\
\hline $305 . \quad \begin{array}{l}\text { the wealth, strength, and } \\
\text { confidence of our country has } \\
\text { disappeared over the horizon }\end{array}$ & LOSING IS MOVING OUT OF SIGHT & Inauguration speech \\
& & \\
\hline
\end{tabular}

\begin{tabular}{llll}
\hline Holding Metaphors & & \\
\hline 306. & who does not grasp this danger & UNDERSTANDING IS HOLDING & Acceptance speech \\
\hline 307. & how out of touch she really is & UNDERSTANDING IS HOLDING & Acceptance speech \\
\hline 308. & $\begin{array}{l}\text { uphold our laws and our } \\
\text { Constitution }\end{array}$ & $\begin{array}{l}\text { ENFORCING LEGISLATION IS } \\
\text { HOLDING UP AN OBJECT }\end{array}$ & Acceptance speech \\
\hline 309. & $\begin{array}{l}\text { I'm reaching out to you for your } \\
\text { guidance and your help }\end{array}$ & POSSESSION IS HOLDING & Victory speech \\
\hline 310. & beyond our reach & POSSESSION IS HOLDING & Victory speech \\
\hline
\end{tabular}

\section{Other Metaphors}

\begin{tabular}{llll}
\hline 311. & number one in her class & BEING THE BEST IS BEING FIRST & Acceptance speech \\
\hline 312. & Third World condition & BEING THE BEST IS BEING FIRST & Acceptance speech \\
\hline 313. & ISIS was not even on the map & EXISTENCE IS BEING ON A MAP & Acceptance speech \\
\hline 314. & thousands of lives lost & DEATH IS LOSS & Acceptance speech \\
\hline 315. & I will outline reforms & REFORMS ARE DRAWINGS & Acceptance speech \\
\hline 316. & reforms that I will outline & REFORMS ARE DRAWINGS & Acceptance speech \\
\hline 317. & She is their puppet & BEING UNDER CONTROL IS BEING A & Acceptance speech \\
& & PUPPET & \\
\hline 318. & they pull the strings & MANIPULATING IS PULLING STRINGS & Acceptance speech \\
\hline 319. & no longer have a voice & OF A PUPPET & \\
\hline 320. & trade deals that strip us of our & INFLUENCE IS VOICE & Acceptance speech \\
\hline & jobs, and strip us of our wealth as & BECOMING NAKED & Acceptance speech \\
& a country & & \\
\hline 321. & the best and brightest prosecutors & INTELLIGENT IS BRIGHT & Acceptance speech \\
\hline 322. & a signature message & A CHARACTERISTIC MESSAGE IS A & Acceptance speech \\
& & SIGNATURE & \\
\hline 323. & signature feature & A CHARACTERISTIC FEATURE IS A & Acceptance speech \\
\hline 324. & brighter future & SIGNATURE & Victory speech \\
\hline
\end{tabular}




\begin{tabular}{|c|c|c|c|}
\hline \# & Text passage & Metaphor & Speech \\
\hline \multicolumn{4}{|c|}{ Other Metaphors } \\
\hline 325. & $\begin{array}{l}\text { we will embark upon a project of } \\
\text { national growth and renewal }\end{array}$ & PROJECTS ARE SHIPS & Victory speech \\
\hline 326. & $\begin{array}{l}\text { we will call upon the best and } \\
\text { brightest }\end{array}$ & INTELLIGENT IS BRIGHT & Victory speech \\
\hline 327. & $\begin{array}{l}\text { they're sharp (about Secret } \\
\text { Service people) }\end{array}$ & INTELLIGENT IS SHARP & Victory speech \\
\hline 328. & $\begin{array}{l}\text { we must think big and dream even } \\
\text { bigger }\end{array}$ & BIG IS GOOD & Inauguration speech \\
\hline 329. & $\begin{array}{l}\text { we stand at the birth of a new } \\
\text { millennium }\end{array}$ & BEGINNING IS BIRTH & Inauguration speech \\
\hline 330. & $\begin{array}{l}\text { we share one heart, one home, } \\
\text { and one glorious destiny }\end{array}$ & UNITY IS SHARING & Inauguration speech \\
\hline 331. & on the other hand & $\begin{array}{l}\text { TWO DIFFERENT OPINIONS ARE TWO } \\
\text { HANDS OF THE BODY }\end{array}$ & Acceptance speech \\
\hline 332. & on the other hand & $\begin{array}{l}\text { TWO DIFFERENT OPINIONS ARE TWO } \\
\text { HANDS OF THE BODY }\end{array}$ & Acceptance speech \\
\hline 333. & on the other hand & $\begin{array}{l}\text { TWO DIFFERENT OPINIONS ARE TWO } \\
\text { HANDS OF THE BODY }\end{array}$ & Acceptance speech \\
\hline 334. & $\begin{array}{l}\text { firing their employees along the } \\
\text { way }\end{array}$ & DESTROYING JOBS IS BURNING & Acceptance speech \\
\hline 335. & $\begin{array}{l}\text { we will determine the course of } \\
\text { America }\end{array}$ & AMERICA IS A SHIP & Inauguration speech \\
\hline 336. & $\begin{array}{l}\text { to impose our way of life on } \\
\text { anyone, but rather to let it shine as } \\
\text { an example for everyone to follow }\end{array}$ & GOOD IS LIGHT & Inauguration speech \\
\hline 337. & $\begin{array}{l}\text { prevent you from speaking your } \\
\text { minds from your own pulpits }\end{array}$ & $\begin{array}{l}\text { EXPRESSING ONE'S OPINION IS } \\
\text { PREACHING }\end{array}$ & Acceptance speech \\
\hline 338. & $\begin{array}{l}\text { (one more child to sacrifice) on } \\
\text { the order and on the altar of open } \\
\text { borders }\end{array}$ & $\begin{array}{l}\text { OPEN BORDERS ARE AN ALTAR FOR } \\
\text { RITUAL SACRIFICE }\end{array}$ & Acceptance speech \\
\hline 339. & $\begin{array}{l}\text { this American carnage stops right } \\
\text { here and stops right now }\end{array}$ & SERIOUS PROBLEMS ARE SLAUGHTER & Inauguration speech \\
\hline 340. & $\begin{array}{l}\text { a country of generosity and } \\
\text { warmth }\end{array}$ & EMOTION IS TEMPERATURE & Acceptance speech \\
\hline 341. & $\begin{array}{l}\text { she was strong, but also warm and } \\
\text { fair-minded }\end{array}$ & KIND IS WARM & Acceptance speech \\
\hline
\end{tabular}




\begin{tabular}{llll}
\hline$\#$ & Text passage & Metaphor & Speech \\
\hline \hline Other Metaphors & & \\
\hline 342. & $\begin{array}{l}\text { to lift the restrictions on the } \\
\text { production of American energy }\end{array}$ & RESTRICTIONS ARE WEIGHT & Acceptance speech \\
\hline 343. & take the pressure off & A FINANCIAL OBLIGATION IS & Acceptance speech \\
& & PRESSURE & \\
\hline 344. & people have borne the cost & EXPENSES ARE BAGGAGE & Inauguration speech \\
\hline 345. & it is finally time for a & TRUTH IS STRAIGHT & Acceptance speech \\
& straightforward assessment of the & & \\
& state of our nation & & Acceptance speech \\
\hline 346. & I will present the facts plainly & TRUTH IS PLAIN & Acceptance speech \\
\hline 347. & plain facts & TRUTH IS PLAIN &
\end{tabular}

